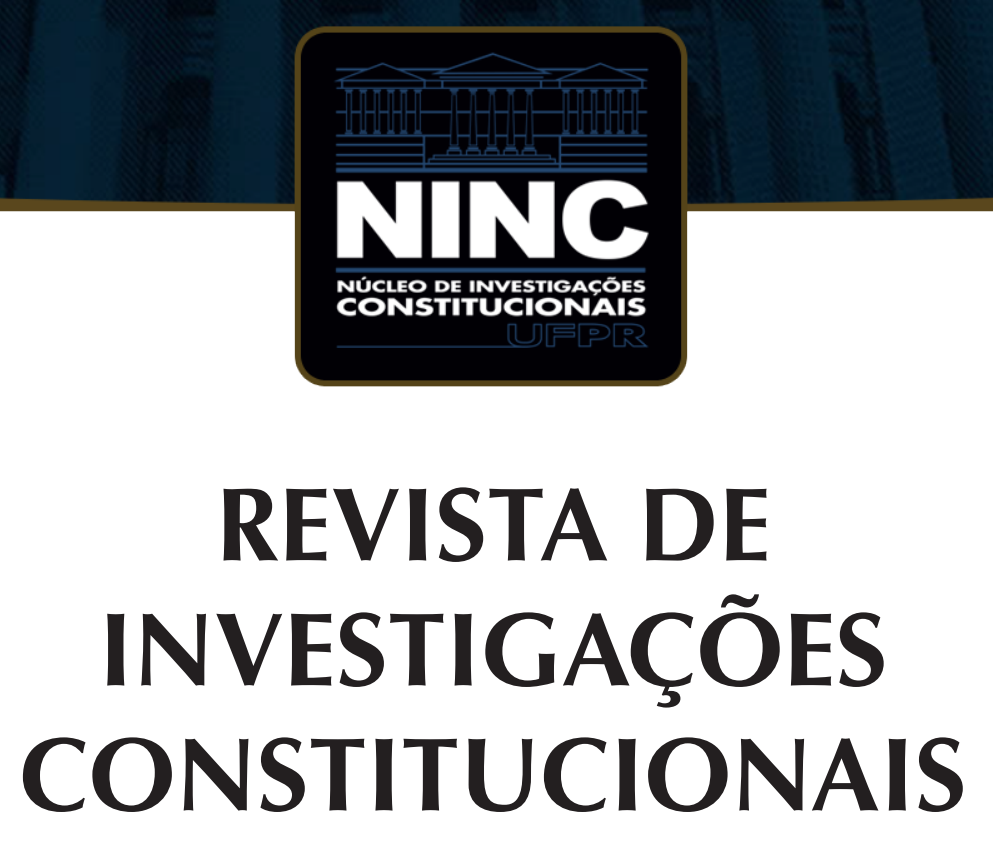

JOURNAL OF CONSTITUTIONAL RESEARCH

vol. 8 | n. 1 | janeiro/abril 2021 | ISSN 2359-5639 | Periodicidade quadrimestral Curitiba | Núcleo de Investigações Constitucionais da UFPR | www.ninc.com.br 


\title{
Criteria to scrutinize new rights: protecting rights against artificial proliferation
}

\section{Critérios para testar novos direitos: protegendo os direitos contra uma proliferação artificial}

\author{
LUÍSA NETTO ${ }^{1, *}$ \\ ' Utrecht University (Utrecht, Netherlands) \\ Icpnetto@gmail.com \\ https://orcid.org/0000-0002-2379-8188 \\ Recebido/Received: 18.02 .2020 / February $18^{\text {th }}, 2020$ \\ Aprovado/Approved: 04.12.2020 / December 4 ${ }^{\text {th }}, 2020$
}

\begin{abstract}
Human and fundamental rights are powerful legal means to protect and promote human dignity. On the one hand, the recognition of implicit and new rights appears unavoidable and desirable as history and its evolving circumstances permanently present new challenges to human dignity. On the other hand, an artificial proliferation of rights can weaken rights' legal and political worth. The rights system cannot expand limitless, hence criteria to test new rights must be construed in the search of adequate parameters to update the system. These criteria should reveal the presence of substantial fundamentality in rights not explicitly or formally enshrined in the constitutional text. The testing path of new rights is conceived as a discursive process which reinforces the mutual relation between rights and democracy.
\end{abstract}

Keywords: fundamental and human rights; rights sys tem; new rights; scrutinizing criteria; substantial fundamentality; rights overreach; democracy and rights.

\section{Resumo}

Os direitos humanos e fundamentais são poderosos instrumentos jurídicos para proteger e promover a dignidade da pessoa humana. Por um lado, o reconhecimento de direitos implícitos e novos direitos se mostra inevitável e desejável, uma vez que o evolver histórico sempre coloca renovados desafios à dignidade da pessoa humana. Por outro lado, uma proliferação artificial de direitos pode enfraquecer seu valor jurídico e político. O sistema de direitos não pode se expandir de forma ilimitada; é então necessária a construção de critérios para buscar uma adequada parametrização da atualização desse sistema. Esses critérios devem revelar a presença de fundamentalidade material em direitos que não foram previstos de maneira expressa no texto constitucional. O caminho para testar novos direitos é concebido como um processo discursivo que reforça a relação mútua entre direitos e democracia.

Palavras-chave: direito fundamentais e humanos; sistema de direitos; novos direitos; critérios para testar novos direitos; fundamentalidade material; proliferação de direitos; democracia e direitos.

Como citar esse artigo/How to cite this article: : NETTO, Luísa. Criteria to scrutinize new rights: protecting rights against artificial proliferation. Revista de Investigações Constitucionais, Curitiba, vol. 8, n. 1, p. 11-75, jan./abr. 2021. DOI: 10.5380/rinc.v8i1.82654.

* Assistant Professor of Law Economics and Government at Utrecht University School of Law (Utrecht, Netherlands). Postdoc researcher at Leiden University. Holds a Ph.D in Law from Lisbon University. Email: Icpnetto@gmail.com. 


\section{CONTENTS}

1. Introduction; 2. The legal system of the constitutional state and the fundamental rights; $\mathbf{3}$. The fundamental rights system of the constitutional state; 4 . The openness of the fundamental rights system - compensatory constitutionalization of rights; 5 . Openness and closure of the fundamental rights system - criteria for approaching substantial fundamentality; $\mathbf{6}$. Closing remarks; 7 . References.

\section{INTRODUCTION}

This paper is built upon the characterization of the fundamental rights system in the constitutional state. In such state - based on the principles of rule of law, democracy and welfare -, human dignity assumes the central role in the legal order. Human dignity is concretized by fundamental rights, which are not confined to a subjective dimension nor to the classical public liberties. Fundamental rights embrace the expansive potentialities of dignity, which constantly faces new necessities and threats. The protection of dignity, hence, requires the permanent updating of the fundamental rights system, imposing its construction as an open system.

The conception of openness developed in the paper cannot be reduced to the existence of explicit open clauses, often present in contemporary constitutions, it identifies a much broader phenomenon. Openness manifests itself in the interpretation and creation of norms through different paths - structural, derived from an implicit principle of openness, and resulting from the interaction between national law and international law-, and counting on various ways of realization. Openness enables to welcome implicit and new rights into the system?'

The acknowledgment of the open character of the system has multiple consequences to this very system, such as the danger of an artificial recognition of fundamental rights, and to the constitutional system, namely to the separation of powers and constitutional normativity. Openness presents the risk of weakening these systems' normative force.

The paper is an attempt to offer theoretical foundations to the openness of the fundamental rights system. The goal is to preserve the core values and elements of the

The core ideas concerning the open nature of the fundamental rights system were initially developed in my Ph.D thesis (NETTO, Luísa Cristina Pinto e. A abertura do sistema de direitos fundamentais do Estado Constitucional. Curitiba: Ithala, 2016).

The original argumentation is being revisited and enriched during the postdoc research periods at the Amsterdam Centre for International Law, Amsterdam University (ACIL - UvA), and at Leiden University. These postdoc periods were made possible due to institutional support provided by the General State Attorney Office for the state of Minas Gerais, the Catholic University of Minas Gerais, and by the universities of Amsterdam and Leiden, where I was welcomed by Professor Yvonne Donders and Professor Wim Voermans, respectively.

The present paper aims to update and deepen those ideas, putting them into discussion within a broader English-speaking audience. New insights and argumentation regard especially the international law on human rights, the relation between rights and democracy, and the challenges posed by an alleged rights overreach. Relevant literature has also been incorporated. 
system and prevent the denaturation of the concept of fundamental rights. The system of fundamental rights cannot expand limitless; openness must be combined with some degree of closure, protecting rights against artificial proliferation.

This is the challenge the paper aims to face; to present and discuss some criteria to identify the substantial fundamentality in rights which are not formally enshrined in constitutional provisions. These criteria should guide the test of new rights which claim compensatory constitutionalization, parametrizing the update of the system.

The paper is organized as follows. The first section offers the underlying conception of the legal system of the constitutional state. The second section provides an overview of the fundamental rights system, exposing its axial elements. The third section presents the understanding of the openness of the fundamental rights system, explaining how the compensatory constitutionalization of new rights can occur. The fourth section delves into the criteria developed to test the substantial fundamentality of new rights. At the end some closing remarks are advanced pointing to possible further research paths.

\section{THE LEGAL SYSTEM OF THE CONSTITUTIONAL STATE AND THE FUNDAMENTAL RIGHTS}

The possible institutional scenario needed to approach the theme can be drafted departing from the generic concept of a democratic nation, suggested by Mark Tushnet ${ }^{2}$; a state built upon the principles of (i) the rule of law ${ }^{3}$, (ii) democracy ${ }^{4}$ and (iii)

2 TUSHNET, Mark. Weak courts, strong rights. Princeton: Princeton University Press, 2009.

3 SANCHÍS, Luis Prieto. Justicia constitucional y derechos fundamentales. Madrid: Trotta, 2003, p. 1213/25; GRIMM, Dieter. The achievement of constitutionalism and its prospects in a changed world. In: DOBNER, Petra; LOUGHLIN, Martin. The twilight of constitutionalism? Oxford: Oxford, 2012, p. 10; ALLAN, T. R. S.. Constitutional rights and the rule of law. In: KLATT, Matthias (ed.). Institutionalized reason: the jurisprudence of Robert Alexy. Oxford: Oxford, 2012, p. 132-142.

4 HABERMAS, Jürgen. The inclusion of the other: studies in political theory. Cambridge: MIT Press, 1998; HABERMAS, Jürgen. Direito e democracia: entre facticidade e validade. v. I. Rio de Janeiro: Tempo Brasileiro, 2012. p. 144-146; STERN, Klaus. Idee der Menschenrechte und Positivität der Grundrechte. In. ISENSEE, Josef; KIRCHHOF, Paul (Hrsg.). Handbuch des Staats Rechts. V, zweite Auflage. Heidelberg: Müller, 2000, p. 22 ss; HESSE, Konrad. Significado de los derechos fundamentales. In: BENDA, Ernst; MAIHOFER, Werner; VOGEL, Hans-Jochen; HESSE, Konrad; HEYDE, Wolfgang. Manual de derecho constitucional. 2.ed. Madrid: Marcial Pons, 2001, p. 89-90; BÖCKENFÖRDE, Ernest-Wolfgang. Estudios sobre el Estado de Derecho y la democracia. Madrid: Trotta, 2000, p. 92 ss; WALDRON, Jeremy. Derecho y desacuerdos. Madrid: Marcial Pons, 2005; DWORKIN, Ronald. Taking rights seriously. Cambridge: Harvard University Press, 1978; ALEXY, Robert. Comments and responses. In: KLATT, Matthias (ed.). Institutionalized reason: the jurisprudence of Robert Alexy. Oxford: Oxford, 2012, p. 330; ALEXY, Robert. La institucionalización de los derechos humanos en el Estado constitucional democrático. Derechos y libertades: Revista del Instituto Bartolomé de las Casas. Madrid, ano V, n. 8, ene./ jun., 2000, p. 40; ALEXY, Robert. Basic rights and democracy in Jürgen Habermas's procedural paradigm of the law. Ratio juris, v. 7, n. 2, jul., 1994, p. 232-235; PULIDO, Carlos Bernal. El principio de proporcionalidad y los derechos fundamentales: el principio de proporcionalidad como criterio para determinar el contenido de los derechos fundamentales vinculante para el Legislador. 3.ed. Madrid: Centro de Estúdios Políticos y Constitucionales, 2007, p. 203-206; BOROWSKI, Martin. La restricción de los derechos fundamentales. Revista Española 
social welfare ${ }^{5}$. The power in this state is constrained by a constitution, which is based on the norm of human dignity and offers ground for the entire legal system.

In this legal institutional design, the rule of law asserts the importance of law as limit and guide to state action. Law is democratically established through the political participation of citizens which are necessarily entitled to legal specific precipitations of human dignity, i.e., fundamental rights. These rights are not confined to public liberties or to the classical negative rights but also impose duties on state towards securing minimum conditions of welfare.

The legal system of this democratic or constitutional state (hereafter interchangeably referred) is an ensemble of norms systematically ordered which holds unity and coherence. Frictions between norms which rest upon axiological tensions may occur and should be approached relying on the system's appetence towards coherent unity. Moreover, this ensemble of norms is not complete or closed, but evolutive, what leads to another characteristic: openness. These characteristics sustain the conception of law as a system structured not only on logical or formal deductions, but on substantial and axiological relations among its norms ${ }^{6}$.

Furthermore, the legal system holds a claim to correctness ${ }^{7}$. This claim, using Robert Alexy's construction, exposes the assumption that there is a necessary connection between law and morality ${ }^{8}$. Law ought to be regarded and structured as a pathway to

de Derecho Constitucional, Madrid, ano 20, n. 59, mayo-agosto, 2000, p. 48; MAIHOFER, Werner. Principios de una democracia en libertad. In: BENDA, Ernst; MAIHOFER, Werner; VOGEL, Hans-Jochen; HESSE, Konrad; HEYDE, Wolfgang. Manual de derecho constitucional. 2.ed. Madrid: Marcial Pons, 2001, p. 227 ss; ZAGREBELSKY, Gustavo. El derecho dúctil: ley, derechos, justicia. 8.ed. Madrid: Trotta, 2008, p. 60.

5 BENDA, Ernst. El Estado social de derecho. In: BENDA, Ernst; MAIHOFER, Werner; VOGEL, Hans-Jochen; HESSE, Konrad; HEYDE, Wolfgang. Manual de derecho constitucional. 2.ed. Madrid: Marcial Pons, 2001, p. 540541; STERN, Klaus. Idee der Menschenrechte und Positivität der Grundrechte. In. ISENSEE, Josef; KIRCHHOF, Paul (Hrsg.). Handbuch des Staats Rechts. V, zweite Auflage. Heidelberg: Müller, 2000, p. 24.

$6 \quad$ The systemic conception of law was develop mostly leaning on the construction of Claus-Wilhelm Canaris (CANARIS, Claus-Wilhelm. Pensamento sistemático e conceito de sistema na ciência do direito. 2.ed. Lisboa: Fundação Calouste Gulbenkian, 1996). To approach a systemic conception of law, contributions of other writers were also welcomed. See, among others BULYGIN, Eugenio; MENDONÇA, Daniel. Normas y sistemas normativos. Madrid: Marcial Pons, 2005; RÜTHERS, Bernd; FISCHER, Christian; BIRK, Axel. Rechtstheorie mit juristischer Methodenlehre. 6. Auf. München: C. H. Beck, 2011, p. 88 ss; GUASTINI, Riccardo. Teoría e ideología de la interpretación constitucional. Madrid:Trotta, 2008, p. 71-72; ALEXY, Robert. Rechtssystem und praktische Vernunft. Rechtstheorie, 18. Band, 1987, Heft 4, p. 409 ss; MODUGNO, Franco. Interpretazione per valori e interpretazione costituzionale. In: AZZARITI, Gaetano. Interpretazione costituzionale. Torino: Giappichelli, 2005, p. 70; LARENZ, Karl. Metodologia da ciência do direito. 3.ed. Lisboa: Fundação Calouste Gulbenkian, 1997.

7 GARDNER, John. How law claims, what law claims. In: KLATT, Matthias (ed.). Institutionalized reason: the jurisprudence of Robert Alexy. Oxford: Oxford, 2012, p. 29-44.

8 On the relation between law and morality, see ALEXY, Robert. On the thesis of a necessary connection between law and morality: Bulygin's critique. Ratio juris, v. 13, n. 2, jun., 2000, p.138-147; ALEXY, Robert. Constitutional rights, balancing and rationality. Ratio juris, v. 16, n. 2, jun., 2003, p. 135; ALEXY, Robert. The nature of legal philosophy. Ratio juris, v. 17, n. 2, jun., 2004, p. 159-160/163 ss; ALEXY, Robert. Comments and responses. In: KLATT, Matthias (ed.). Institutionalized reason: the jurisprudence of Robert Alexy. Oxford: Oxford, 2012, p. 319-324; KLATT, Matthias. Robert Alexy's philosophy of law as system. In: KLATT, Matthias (ed.). 
achieve goals related to correction and justice. Consequently, not every content should be possible within the legal system; its fundamental principles, as well as its rules, must be justifiable by means of rational arguments ${ }^{9}$. The claim to correctness imposes substantial requirements on the legal system. Nonetheless, it does not imply a metaphysical morality, instead, it relies on a universalist morality based on procedural discursive ethics ${ }^{10}$.

This conception of law, a systematic set of norms - rules and principles - that holds a claim to correctness, requires procedures to ensure rationality ("rationalitätssichernde Prozedur"); the claim to correctness leads to a claim to justifiability. What is at stake is the rational grounding and evaluation of axiological choices and decisions. When law is conceived as related to morality, as an open system, legal argumentation becomes essential ${ }^{11}$.

From another perspective, the constitution is central to this conception of law. The constitution, with its undeniable normative nature, stands on the top of the legal system and congregates the most important decisions on the coexistence of the political community and the state. This paramount legal ensemble has the role of constituting power, not only modifying it. In addition, it ought to guarantee the democratic exercise of political power, marking the procedural and substantial boundaries within which the democratic game can unfold legitimately ${ }^{12}$. Constitutional norms compose

Institutionalized reason: the jurisprudence of Robert Alexy. Oxford: Oxford, 2012, p. 12-13; GARDNER, John. How law claims, what law claims. In: KLATT, Matthias (ed.). Institutionalized reason: the jurisprudence of Robert Alexy. Oxford: Oxford, 2012, p. 29-44; MURPHY, Mark C.. Defect and deviance in natural law jurisprudence. In: KLATT, Matthias (ed.). Institutionalized reason: the jurisprudence of Robert Alexy. Oxford: Oxford, 2012, p. 54-60; SIECKMANN, Jan-R.. Los derechos fundamentales como princípios. In: SIECKMANN, Jan-R.. (ed.) La teoría principialista de los derechos fundamentales: estudios sobre la teoría de los derechos fundamentales de Robert Alexy. Madrid: Marcial Pons, 2011, p. 38-39; POSCHER, Ralf. The principles theory: how many theories and what is their merit? In: KLATT, Matthias (ed.). Institutionalized reason: the jurisprudence of Robert Alexy. Oxford: Oxford, 2012, p. 221-229; BULYGIN, Eugenio. Alexy's thesis of the necessary connection between law and morality. Ratio juris, v. 13, n. 2, jun., 2000, p. 133-137; HART, H. L. A. O conceito de direito. 5.ed. Lisboa: Calouste Gulbenkian, 2007, p. 201 ss.

9 ALEXY, Robert. On the thesis of a necessary conexion between law and morality: Bulygin's critique. Ratio juris, v. 13, n. 2, jun., 2000, p.138-147; SANCHÍS, Luis Prieto. Justicia constitucional y derechos fundamentales. Madrid: Trotta, 2003, p. 97.

10 On the claim to correctness, see ALEXY, Robert. Comments and responses. In: KLATT, Matthias (ed.). Institutionalized reason: the jurisprudence of Robert Alexy. Oxford: Oxford, 2012, p. 319-322; KLATT, Matthias. Robert Alexy's philosophy of law as system. In: KLATT, Matthias (ed.). Institutionalized reason: the jurisprudence of Robert Alexy. Oxford: Oxford, 2012, pp. 5; GARDNER, John. How law claims, what law claims. In: KLATT, Matthias (ed.). Institutionalized reason: the jurisprudence of Robert Alexy. Oxford: Oxford, 2012, p. 29-44.

11 ALEXY, Robert. Rechtssystem und praktische Vernunft. Rechtstheorie, 18. Band, 1987, Heft 4, p. 416 ss; ALEXY, Robert. A theory of legal argumentation: the theory of rational discourse as theory of legal justification. Oxford University Press, 2010.

12 See, among others, HESSE, Konrad. Constitución y derecho constitucional. In: BENDA, Ernst; MAIHOFER, Werner; VOGEL, Hans-Jochen; HESSE, Konrad; HEYDE, Wolfgang. Manual de derecho constitucional. 2.ed. Madrid: Marcial Pons, 2001, p. 2 ss; GRIMM, Dieter. Constitucionalismo y derechos fundamentales. Madrid: Trotta, 2006, p. 27 ss; ZAGREBELSKY, Gustavo. El derecho dúctil: ley, derechos, justicia. 8.ed. Madrid: Trotta, 
a system which combines impositions, prohibitions and permissions concerning the state powers ${ }^{13}$.

The constitution is a key legal element in the social plurality of the democratic state. Still departing from a monistic legitimacy foundation, through the affirmation of the democratic principle combined with popular sovereignty, the constitution appears as the central and paramount normative element that guarantees state unity and drives political processes. The constitution becomes a "concrete-historical order of secularized and pluralist political societies", an essential element in the face of the growing axiological cleavages which inform the constitutional consent and are present in the constitutional practice ${ }^{14}$.

In addition, fundamental rights understood as principles have a substantial impact on the conception of the constitution ${ }^{15}$. Within the legal system of the democratic

2008, p. 39 ss; GUASTINI, Riccardo. Teoría e ideología de la interpretación constitucional, p. 48-49; ALEXY, Robert. Rechtssystem und praktische Vernunft. Rechtstheorie, 18. Band, 1987, Heft 4, p. 405.

13 ALEXY, Robert. A theory of constitutional rights. Oxford: Oxford University Press, 2010; ALEXY, Robert. Comments and responses. In: KLATT, Matthias (ed.). Institutionalized reason: the jurisprudence of Robert Alexy. Oxford: Oxford, 2012, p. 343. See also JESTAEDT, Matthias. The doctrine of balancing: its strengths and weaknesses. In: KLATT, Matthias (ed.). Institutionalized reason: the jurisprudence of Robert Alexy. Oxford: Oxford, 2012, p. 167-169; KUMM, Mattias. Alexy's theory of constitutional rights and the problem of judicial review. In: KLATT, Matthias (ed.). Institutionalized reason: the jurisprudence of Robert Alexy. Oxford: Oxford, 2012, p. 209 ss; KLATT, Matthias. Robert Alexy's philosophy of law as system. In: KLATT, Matthias (ed.). Institutionalized reason: the jurisprudence of Robert Alexy. Oxford: Oxford, 2012, p. 16: POSCHER, Ralf. The principles theory: how many theories and what is their merit? In: KLATT, Matthias (ed.). Institutionalized reason: the jurisprudence of Robert Alexy. Oxford: Oxford, 2012, p. 218-247; SIECKMANN, Jan-R.. Los derechos fundamentales como princípios. In: SIECKMANN, Jan-R.. (ed.) La teoría principialista de los derechos fundamentales: estudios sobre la teoría de los derechos fundamentales de Robert Alexy. Madrid: Marcial Pons, 2011, p. 27-50: PULIDO, Carlos Bernal. El principio de proporcionalidad y los derechos fundamentales: el principio de proporcionalidad como criterio para determinar el contenido de los derechos fundamentales vinculante para el Legislador. 3.ed. Madrid: Centro de Estúdios Políticos y Constitucionales, 2007. 883 p; POSCHER, Ralf. Aciertos, errores y falso autoconcepto de la teoría de los princípios. In: SIECKMANN, Jan-R.. (ed.) La teoría principialista de los derechos fundamentales: estudios sobre la teoría de los derechos fundamentales de Robert Alexy. Madrid: Marcial Pons, 2011, p. 71-92.

14 ZAGREBELSKY, Gustavo. El derecho dúctil: ley, derechos, justicia. 8.ed. Madrid: Trotta, 2008, p. 12-13/3739/114 ss/151 ss; SANCHÍS, Luis Prieto. Justicia constitucional y derechos fundamentales. Madrid: Trotta, 2003, p. 122-124.

15 The expression chosen to refer these rights in this paper is "fundamental rights" as it is at the moment, to a certain extent, an acquis in many domestic traditions and constitutions, such as in the Portuguese speaking countries ("direitos fundamentais"), in many Spanish speaking countries ("derechos fundamentales"), in Italy ("diritti fondamentali") and even in France, the crib of public liberties ("droits fondamentaux"). In the German scenario, the expression commonly found is "Grundrechte" which would possibly lead to different translation options, such as basic rights. In Dutch one would also speak of "grondrechten". It seems relevant to note that Robert Alexy wrote his theory on the "Grundrechte" (Theorie der Grundrechte) which has been translated in Spanish and Portuguese using the expression "fundamental rights". Nonetheless, in the English translation the expression chosen was "constitutional rights" (ALEXY, Robert. A theory of constitutional rights. Oxford: Oxford University Press, 2010).

Having exposed the translation idiosyncrasies, what should be held is that these are the rights that structure the relation between individuals and the state and to some extent between individuals and private actors yielding power. These rights are regarded as so important that they deserve guarantee on the constitutional level, so they combine their substantial importance with a formal normative status that enables them to 
state, the set of fundamental rights gains relevance, tracing the individual status vis $a$ vis the state and in many aspects vis $a$ vis other individuals and organizations ${ }^{16}$. The democratic state is impregnated by fundamental rights (grundrechtsdurchdrungenen Verfassungsstaat), whose systemic structuration takes part in building the state identity ${ }^{17}$. In other words, the set of fundamental rights is required to enable law to fulfil the claim to correctness.

Specifically considered, fundamental rights are legal subjective advantage positions linked (in distinct intensity) to human dignity. This relation to human dignity reveals the substantial fundamentality of the rights. Fundamental rights are positivized in a state legal order, preferably in its constitution, as legal norms with subjective and objective content, safeguarded against and through state powers. Nonetheless, fundamental rights, even regarded as positivized legal norms, should not be conceived as pure states' concessions towards individuals. They are necessary norms in a democratic state legal system because they are the most concrete and specific legal protection for human dignity.

As fundamental rights are positivized in the constitution, they profit from formal fundamentality; they explicitly have constitutional status. The theoretical and practical consequences of this status can be found in the protection granted to constitutional norms, as they are situated on the top of the normative hierarchy. On the one hand, fundamental rights norms are protected from the ordinary legislative activity and require, in general, special procedures to be modified through constitutional amendment. On the other hand, they claim a minimum of effectiveness imposing legislative and executive action, as well as judicial activity in case of violation.

The paramount set of norms organized in the constitution is meant to have some stability and endure historical changes. Nevertheless, to persevere through time, constitution must combine a stable core identity with the possibility of adaptation. Through evolutive interpretation and amendments, the constitution can live up to new needs and burdens laid on the legal system.

In the same way, the enumeration of constitutional rights should not be immutable. It is not feasible that the constituent power would be able to write down all rights required to warrant human dignity. Even if the enumeration of rights could be

\footnotetext{
protect human dignity. Substantial fundamentality is conjugated with formal fundamentality, i.e., the positivation in the Constitution to save them from political conjunctural majorities. See on this positivation HESSE, Konrad. Constitución y derecho constitucional. In: BENDA, Ernst; MAIHOFER, Werner; VOGEL, Hans-Jochen; HESSE, Konrad; HEYDE, Wolfgang. Manual de derecho constitucional. 2.ed. Madrid: Marcial Pons, 2001, p. 5; STERN, Klaus. Idee der Menschenrechte und Positivität der Grundrechte. In. ISENSEE, Josef; KIRCHHOF, Paul (Hrsg.). Handbuch des Staats Rechts. V, zweite Auflage. Heidelberg: Müller, 2000, p. 12/20 ss.

16 STERN, Klaus. Idee der Menschenrechte und Positivität der Grundrechte. In. ISENSEE, Josef; KIRCHHOF, Paul (Hrsg.). Handbuch des Staats Rechts. V, zweite Auflage. Heidelberg: Müller, 2000, p. 21

17 STERN, Klaus. Idee der Menschenrechte und Positivität der Grundrechte. In. ISENSEE, Josef; KIRCHHOF, Paul (Hrsg.). Handbuch des Staats Rechts. V, zweite Auflage. Heidelberg: Müller, 2000, p. 5.
} 
adequate at a specific historical time, the evolving circumstances would always be able to present renewed challenges either to human dignity or to is integration in the political community.

The recognition of the incompleteness or openness of the constitutional enumeration of rights brings to light that not all the rights that carry substantive fundamentality are constitutionally positivized and might claim compensatory constitutionalization, to borrow Anne Peters' expression ${ }^{18}$.

Even though the idea of openness of the set of fundamental or human rights ${ }^{19}$ is not novel, it requires being systematically addressed ${ }^{20}$. The following section attempts to present this systematic approach.

\section{THE FUNDAMENTAL RIGHTS SYSTEM OF THE CONSTITUTIO- NAL STATE}

Notwithstanding the existence of remarkably diverse concrete fundamental rights systems enshrined in the various domestic constitutions ${ }^{21}$, it is possible to work with a generalization, likewise above suggested regarding the democratic or

18 PETERS, Anne. Compensatory constitutionalism: the function and potential of fundamental international norms and structures. Leiden Journal of International Law. Vol. 19, pp. 579-610, 2006.

19 Fundamental and human rights cannot simply be considered synonyms. They constitute close but differentiated categories. "Fundamental rights" is the expression that more precisely indicates human rights that have been positivized in a domestic legal order, i.e., that are foremost enshrined by constitutional provisions. This definition brings about important consequences on the enforcement and justiciability of these rights in the domestic arena. "Human rights" are a broader concept that goes beyond domestic legal orders and constitutional positivation; these rights claim to be universal and, to a certain extent, they impose themselves to states departing from various international law norms. The expressions are often used interchangeably, not disregarding these differences. In fact, beyond these differences it is possible to point out many rapprochements and the undeniable mutual influence exercised by both the fundamental rights systems and the international human rights system.

20 Much has been written on "constitutional open clauses", but not much can be found on the broader openness phenomenon. About open clauses, see, for a first approach, in the United States: TRIBE, Laurence H. American constitutional law. 2.ed. New York: The Foundation Press, 1988, p. 774-775. In Portugal: GOUVEIA, Jorge Bacelar. Os direitos fundamentais atípicos. Lisboa: Aequitas, 1995, p. 152ss; MIRANDA, Jorge. A abertura constitucional a novos direitos fundamentais. Estudos em homenagem ao professor doutor Manuel Gomes da Silva. Coimbra: Coimbra, 2001, p. 562-563; CANOTILHO, J. J. Gomes. Direito constitucional e teoria da constituição. 7.ed. Coimbra: Almedina, 2003, p. 403ss; OTERO, Paulo. Direitos históricos e não tipicidade pretérita dos direitos fundamentais. In: Ab vno ad omnes: 75 anos da Coimbra Editora. Coimbra: Coimbra, 1995, p. 1061-1090; ALEXANDRINO, José de Melo. A estruturação do sistema de direitos, liberdades e garantias na constituição portuguesa: a construção dogmática. v. II. Coimbra: Almedina, 2006, p. 381ss. In Brazil: SARLET, Ingo Wolfgang. A eficácia dos direitos fundamentais. 10.ed. Porto Alegre: Livraria do Advogado, 2009, p. 90ss; TRINDADE, Antônio Augusto Cançado. Tratado de direito internacional dos direitos humanos. v. II. Porto Alegre: Sergio Antonio Fabris, 1999; PIOVESAN, Flávia. Direitos humanos e o direito constitucional internacional. 13.ed. São Paulo: Saraiva, 2012.

21 Every concrete system carries specificities and is to a certain extent product of social, historical, cultural and economic circumstances (STERN, Klaus. Idee der Menschenrechte und Positivität der Grundrechte. In. ISENSEE, Josef; KIRCHHOF, Paul (Hrsg.). Handbuch des Staats Rechts. V, zweite Auflage. Heidelberg: Müller, 2000, p. 47; PECES-BARBA MARTÍNEZ, Gregorio; ASÍS ROIG, Rafael; BARRANCO AVILÉS, María del Carmen. Lecciones de derechos fundamentales. Madrid: Dykinson, 2004, p. 249). 
constitutional state. The aim is to approach this general rights system of the constitutional state; to reveal the components inherent to fundamental rights norms; to advance their sustaining principles (tragenden Prlnzipien) and their meaning connections (SInnzusammenhänge). The underlying purpose is to order the fundamental rights norms to fulfil theoretical and practical goals. This purpose is grounded on the premise that there is an inherent systemic connection linking the fundamental contents; fundamental rights converge into a system (systemkonvergent) ${ }^{22}$. The system is not axiomatic, logical or deductive, its inner connections derive from its positivized axiological content.

Based on these ideas, the structuration of the fundamental rights system can be embedded in its substantive connections and developed departing from the following elements ${ }^{23}$ :

1. Structuring elements: human dignity, freedom, equality, solidarity;

2. Forming elements - fundamental rights norms: explicit positivation, joint positivation of liberty rights and social rights (negative and positive rights), indivisibility and interdependence of various categories of rights, positivation through a combined model of rules and principles, restrictability;

3. Warranting elements - norms on fundamental rights: efficacy provisions, limits on limits, endurance ability, legal protection, support on international norms.

These elements will not be deeply analysed in this paper; instead, they are shortly named to contextualize the axial ideas underlying the systemic conception of rights ${ }^{24}$.

The structuring elements are the ones on which the system relays, they serve as axiological and substantive foundations to the system, providing coherence and unity.

The first structuring element is human dignity. The conception of human dignity rests upon jusnaturalist roots ${ }^{25}$, specially laid down in the western tradition by Immanuel Kant. Human dignity, as the core of human personality, marks the boundaries for the relations between state and individuals and between individuals. For Kant, the individual is always an end in itself and never a means; each and every person is worthy and deserves to be respected. Dignity places every individual in equal standing, even if formally; every individual has equal dignity and ought to respect others' dignities.

22 STERN, Klaus. Idee und Elemente eines Systems der Grundrechte. In. ISENSEE, Josef; KIRCHHOF, Paul (Hrsg.). Handbuch des Staats Rechts. V, zweite Auflage. Heidelberg: Müller, 2000, p. 63.

${ }_{23}$ For a complete development of these ideas, see $\mathbf{A}$ abertura do sistema de direitos fundamentais do Estado Constitucional. Curitiba: Íthala, 2016.

24 For a deeper development on the rights system, see NETTO, Luísa Cristina Pinto e. A abertura do sistema de direitos fundamentais do Estado Constitucional. Curitiba: Íthala, 2016.

25 STERN, Klaus. Idee der Menschenrechte und Positivität der Grundrechte. In. ISENSEE, Josef; KIRCHHOF, Paul (Hrsg.). Handbuch des Staats Rechts. V, zweite Auflage. Heidelberg: Müller, 2000, p. 6 ss. 
Moreover, dignity has no price; it has an absolute value. In the Kantian construction, dignity finds its foundation in autonomy; autonomy, in its turn, finds limits in dignity ${ }^{26}$.

The importance of moral considerations on human dignity is undoubtful. Nonetheless, human dignity must also be regarded as a legal norm enshrined in the constitution as the foundation of the legal system, precipitating into specific fundamental rights norms ${ }^{27}$. Besides these core ideas, it is essential to conceive dignity in a social insertion of the individual, connecting him or her to the political community and with his or her multiple roles, as a person, citizen, worker, and as an inhabitant of a planet with limited resources.

From another perspective, it is relevant to advance that human dignity, as the grounding norm of the legal system, must be approached as an open conception, not as an official concept. The protection offered by this legal norm also assures that each individual is entitled to defining his or her own understanding of dignity, within the essential boundaries of the system ${ }^{28}$. Human dignity is the ultimate goal of fundamental rights and it works as a door to the updating re-readings of fundamental rights norms ${ }^{29}$.

In addition to human dignity, there are other structural elements: freedom, equality, solidarity. Hereby, freedom is briefly understood as protection against the state and through the state; it refers to the idea of restraining power by law to favour the individual. Freedom was the first substantial grounding for rights, revealing their first defensive function ${ }^{30}$. Departing from a formal conception, freedom unfolded into a sphere of factual consideration, which requires the possibility and the means for individuals to determine their own life choices and to equally participate in the political community ${ }^{31}$. Freedom in the constitutional state is not absolute; it is social bond and

26 KANT, Immanuel. Groundwork of the metaphysics of Morals. Cambridge: Cambridge.

27 ALEXY, Robert. Teoría de los derechos fundamentales. 2.ed. Madrid: Centro de Estudios Políticos y Constitucionales, 2007, p. 106-109/344-345; PECES-BARBA MARTÍNEZ, Gregorio; ASÍS ROIG, Rafael; BARRANCO AVILÉS, María del Carmen. Lecciones de derechos fundamentales. Madrid: Dykinson, 2004, p. 248.

28 STERN, Klaus. Idee der Menschenrechte und Positivität der Grundrechte. In. ISENSEE, Josef; KIRCHHOF, Paul (Hrsg.). Handbuch des Staats Rechts. V, zweite Auflage. Heidelberg: Müller, 2000, p. 7; BENDA, Ernst. Dignidad humana y derechos de la personalidad, p. 124; ZAGREBELSKY, Gustavo. El derecho dúctil: ley, derechos, justicia. 8.ed. Madrid: Trotta, 2008, p. 17-18.

29 HABERMAS, Jürgen. O conceito de dignidade humana e a utopia realista dos direitos humanos. In: HABERMAS, Jürgen. Sobre a constituição da Europa: um ensaio. São Paulo: Unesp, 2012, p. 9-10; BENDA, Ernst. Dignidad humana y derechos de la personalidad, p. 117; STERN, Klaus. Idee der Menschenrechte und Positivität der Grundrechte. In. ISENSEE, Josef; KIRCHHOF, Paul (Hrsg.). Handbuch des Staats Rechts. V, zweite Auflage. Heidelberg: Müller, 2000, p. 7; HESSE, Konrad. Significado de los derechos fundamentales, p. 87.

30 STERN, Klaus. Idee und Elemente eines Systems der Grundrechte. In. ISENSEE, Josef; KIRCHHOF, Paul (Hrsg.). Handbuch des Staats Rechts. V, zweite Auflage. Heidelberg: Müller, p. 97-98; STERN, Klaus. Idee der Menschenrechte und Positivität der Grundrechte. In. ISENSEE, Josef; KIRCHHOF, Paul (Hrsg.). Handbuch des Staats Rechts. V, zweite Auflage. Heidelberg: Müller, 2000, p. 21; GRIMM, Dieter. Constitucionalismo y derechos fundamentales. Madrid: Trotta, 2006, p. 77 ss.

31 ALEXY, Robert. Teoría de los derechos fundamentales. 2.ed. Madrid: Centro de Estudios Políticos y Constitucionales, 2007, p. 494 ss. 
parametrized by the other constituent values of the legal order, such as equality, solidarity and the duties imposed by sustainability ${ }^{32}$.

Equality, concisely considered as a structuring element of the rights system, means equal treatment and consideration ${ }^{33}$ by the state concerning actions and abstentions and equal participation in the exercise of democratic political power ${ }^{34}$. Moreover, equality goes hand in hand with an idea of justice incorporated in the legal system; equality legitimated as an open space where different conceptions of justice welcomed by the constitution can confront themselves through democratic processes and pursue actualization $^{35}$.

In a nutshell, for its turn, solidarity participates in structuring the system by imposing to the state the fulfilment of duties of welfare required by human dignity. The state has to warrantee a minimum material support for a dignified life by means of actions and abstentions, normative and concrete behaviours. Besides, the state ought to interact with society aiming at welfare. Solidarity as an element of the fundamental rights system enables to conceive freedom and equality in a not antagonistic or incompatible relation. Therefore, sociality becomes a constitutive aspect of freedom, it imposes duties on state and urges the participation of society in the pursuit of collective welfare. From another point of view, solidarity conveys to the system a new role for rights; fundamental rights demand the preservation of the planet for future generations and other species.

In conjunction with these structuring elements, the system holds forming elements, which concern the nature of the fundamental rights norms themselves and how they are positivized. In the democratic state, the rights system requires explicit positivation of fundamental rights norms, it is not enough to establish general clauses, such as human dignity, rule of law or welfare state. Constitutional norms must directly convey fundamental rights and combine negative with positive rights ${ }^{36}$.

From a theoretical point of view, which depends on the wording of the constitutional provisions, fundamental rights ought to be conceived in a combined model of rules and principles ${ }^{37}$. On the one hand, rules provide for immediate normative answers delivering security and determinability. On the other hand, principles function as respirators to the system due to their more general and comprehensive regulation ability

32 STERN, Klaus. Idee und Elemente eines Systems der Grundrechte. In. ISENSEE, Josef; KIRCHHOF, Paul (Hrsg.). Handbuch des Staats Rechts. V, zweite Auflage. Heidelberg: Müller, 2000, p. 53.

33 DWORKIN, Ronald. Taking rights seriously. Cambridge: Harvard University Press, 1978.

34 STERN, Klaus. Idee der Menschenrechte und Positivität der Grundrechte. In. ISENSEE, Josef; KIRCHHOF, Paul (Hrsg.). Handbuch des Staats Rechts. V, zweite Auflage. Heidelberg: Müller, 2000, p. 22-23

35 ZAGREBELSKY, Gustavo. El derecho dúctil: ley, derechos, justicia. 8.ed. Madrid: Trotta, 2008, p. 95 ss.

36 WEBER, Albrecht. L'État social et les droits sociaux en RFA. Révue française de droit constitutionnel, Paris, n. 24, 1995, p. 681.

37 ALEXY, Robert. A theory of constitutional rights. Oxford: Oxford University Press, 2010, p. 80 ss. 
and their behaviour in normative conflicts. Besides, principles lead to conceive rights as more far-reaching than their minimum or core contents, they enable the idea of prima

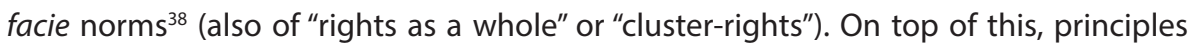
elucidate that every right in the system is intrinsically restrictable ${ }^{39}$.

In addition to the specific fundamental rights norms, the system encompasses norms on rights, norms that discipline the regulatory behaviour of rights norms. These norms on norms are the warranting elements of the system. In this general system here briefly presented, norms that establish the efficacy of fundamental rights norms are warranting elements; they may grant fundamental rights norms immediate efficacy and they regulate fundamental rights norms interpretation. Within the warranting elements, norms concerning the legal means of protecting fundamental rights ought to be established, such as access to justice, judicial protection with its processual and procedural means.

Because fundamental rights often demand legislative action in order to be effective, constitutional norms which provide protection against insufficient or erosive legislative action should also figure among the warranting elements of the system. Beyond that, a crucial warranting element concerns the protection of fundamental rights against constitutional amendments, providing them some capacity to resist, guaranteeing them the status of substantive limitations on constitutional amendments.

Finally, the protection required by fundamental rights also rests on the interaction between national and international law. Constitutional provisions that anchor domestic fundamental rights in international law and open the domestic legal order to international norms are essential warranting elements of the rights system.

These are the axial guidelines which allow to understand the set of rights in the constitutional state as a system and pave the path for exposing the open nature of this system. As a matter of fact, openness itself, which will be addressed in the following section, constitutes an overarching warranting element of the rights system.

\section{THE OPENNESS OF THE FUNDAMENTAL RIGHTS SYSTEM - COMPENSATORY CONSTITUTIONALIZATION OF RIGHTS}

The rights system of the constitutional state as here conceived is an open system; it is not immutable nor complete, it is capable of welcoming renewed interpretations and new rights. The openness of the system appears threefold; it is a structural condition; it is commanded by an implicit principle; and it is imposed by international law. Furthermore, openness operates on two levels, not always wholly distinguishable: interpretation and creation of norms.

38 ALEXY, Robert. A theory of constitutional rights. Oxford: Oxford University Press, 2010, p. 57-59.

39 ALEXY, Robert. A theory of constitutional rights. Oxford: Oxford University Press, 2010. 
In order to affirm openness as an intrinsic characteristic of the system, grounding reasons must be presented. First, structural openness is a consequence of the nature of legal norms, of the wording of constitutional norms and of the presence of positivized general clauses and general rights. Structural openness converges to the open texture of law, as shall be explained hereafter.

From another perspective, since the assumption is that openness, in one of its façades, is an implicit principle which belongs to the system, it is imperative to advance its normative anchors. In the domestic constitutional order, a general foundation for the principle of openness can be found in the norm of human dignity and in the democratic principle. A specific foundation should be sought in constitutional explicit open clauses; in norms which determine the reception of international law norms; in explicit norms of fundamental rights (general or specific rights); in norms which establish fundamental rights regime; and in norms which grant legislative and constitutional amendment competences. All these explicit norms offer normative foundation to an implicit principle which commands that the rights system must evolve to protect human dignity.

Finally, openness towards international law can be justified by means of constitutional provisions which determine the domestic incorporation of international nor$\mathrm{ms}$, as well as provisions which recognize guiding interpretative authority to international norms and standards. In addition, it is possible to affirm that openness is imposed by international law based on the jus cogens nature of some of its norms.

To make these ideas clearer, it seems adequate to address the various ways in which openness unfolds.

\subsection{Structural openness}

The legal system is understood as an open system and so is the fundamental rights one; an open set of principles and rules, with substantial unity, coherence and claim to correctness as briefly exposed above.

Openness derives from the characteristics of language, which inevitably leads to law's open texture. The legal norm is not a given to be found or discovered but a meaning to be construed departing from the text of the legal provision and from the other systemic legal elements. The norm is formulated through interpretation, which relies upon rational argumentative processes to support the meaning defended ${ }^{40}$. Interpre-

40 For a similar approach to interpretation, but then especially concerning international law, see VENZKE, Ingo. Understanding the authority of international courts and tribunals: on delegation and discursive construction. Theoretical Inquiries in Law, 14(2), 381-409, 2013. https://doi.org/10.1515/til-2013-020; VENZKE, Ingo, Authoritative Interpretation (October 11, 2018) In: Max Planck Encyclopedia of International Procedural Law; Amsterdam Law School Research Paper No. 2018-28; Amsterdam Center for International Law No. 2018-10. Available at SSRN: https://ssrn.com/abstract=3264566; VENZKE, Ingo, The Practice of Interpretation 
tation reveals the probable and possible meanings that should be justifiable within the textual and systemic boundaries ${ }^{41}$. There is no such only one right meaning to be discovered departing from every legal text or provision. On the contrary, there are various interpretations that deliver possible norms which claim to be adequately and sufficiently justified. There is an indeterminacy in law which cannot be eliminated, even when it is desirable and viable to establish mechanisms to limit indeterminacy and enhance legal security. Indeterminacy is part of law's nature ${ }^{42}$.

The open texture mentioned is even more present in constitutional provisions, including fundamental rights ones ${ }^{43}$, for reasons that cannot be addressed in this occasion. It is enough to notice the remarkable indeterminacy in the field of rights, which leads to the structural openness of the rights system.

On the structural level, it is possible to explore the phenomenon of construing unwritten or unenumerated rights: rights norms which are implicit in constitutional general clauses and general rights. As Robert Alexy explains, "derivative norms" 44 can be construed and grounded departing from other explicit constitutional norms. In fact, constitutional general clauses positivized as norms, such as human dignity, welfare sta$\mathrm{te}^{45}$, rule of law, equality, as well as general rights, such as general liberty right ${ }^{46}$, general

in International Law: Strategies of Critique (September 10, 2018). Accepted paper In: International Legal Theory: Foundations and Frontiers (edited by Jeff Dunoff \& Mark A. Pollack, CUP 2019); Amsterdam Law School Research Paper No. 2018-22; Amsterdam Center for International Law No. 2018-07. Available at SSRN: https:// ssrn.com/abstract $=3247125$.

41 On textual limits, among others, see SCHAUER, Frederick. Balancing, subsumption, and the constraining role of legal text. In: KLATT, Matthias (ed.). Institutionalized reason: the jurisprudence of Robert Alexy. Oxford: Oxford, 2012, p. 307-316.

42 Important input to the discussion on positivism, law's indeterminacy and judicial discretion can be found comparing the contributions of Herbert L. A. Hart (HART, Herbert L. A. The concept of law. Oxford. 2012, especially p. 124 ss) and of Ronald Dworkin (DWORKIN, Ronald. Taking rights seriously. Cambridge: Harvard University Press, 1978; DWORKIN, Ronald. O império do direito. São Paulo: Martins Fontes, 1999; DWORKIN, Ronald. Uma questão de princípio. São Paulo: Martins Fontes, 2000).

To approach the discussion, see SHAPIRO, Scott J., The Hart-Dworkin Debate: A short guide for the perplexed (March 5, 2007). Available at SSRN: https://ssrn.com/abstract=968657 or http://dx.doi.org/10.2139/ ssrn.968657; BIX, Brian. H. L. A. Hart and the "Open Texture" of Language. Springer. Law and Philosophy, Vol. 10, No. 1 (Feb., 1991); BIX, Brian. Law, Language, and Legal Determinacy. Published to Oxford Scholarship Online: March 2012. DOI: 10.1093/acprof:oso/9780198260509.001.0001.

43 Calling attention to the open texture of law concerning human rights provisions, see ECKES, Christina. Integrated rights protection in the European and International Context: some reflections about limits and consequences. In GOVAERE, I., GARBEN, S. (Eds.). Interfaces between European and International Law (pp. 101-124). (Modern Studies in European Law; Vol. 89). Oxford: Hart Publishing, 2019. https://doi. org/10.5040/9781509923410.

44 ALEXY, Robert. A theory of constitutional rights. Oxford: Oxford University Press, 2010, p. 38-43.

45 ALEXY, Robert. Teoría de los derechos fundamentales. 2.ed. Madrid: Centro de Estudios Políticos y Constitucionales, 2007, p. 419-420. See also, not necessarily with the same understanding, WEBER, Albrecht. L'État social et les droits sociaux en RFA. Révue française de droit constitutionnel, Paris, n. 24, 1995, p. 684-685.

46 STERN, Klaus. Idee und Elemente eines Systems der Grundrechte. In. ISENSEE, Josef; KIRCHHOF, Paul (Hrsg.). Handbuch des Staats Rechts. V, zweite Auflage. Heidelberg: Müller, 2000, p. 97 ss. 
equality right ${ }^{47}$, right to the development of personality, make the structural openness patent in the field of fundamental rights. The general clauses and rights enable to anchor implicit or unwritten rights in their provisions; they provide legal reasons to justify the interpretative results which recognize these derivative norms as part of the system.

In addition, the objective dimension of fundamental rights - a concept connected with the irradiating efficacy of fundamental rights ${ }^{48}$ - may be relevant in regard to the structural openness. The objective dimension determines that state powers ought to conform the legal system according to fundamental rights. State duties are to be derived from this objective dimension: duty to create and enact norms required by fundamental rights, duty to structure organization and procedures required by fundamental rights ${ }^{49}$. From this objective dimension, it is possible, under certain circumstances and with caution, to derive new subjective fundamental positions ${ }^{50}$ which update and enrich the system.

Another interpretative tool in the field of structural openness can be found in the conception of broad fundamental rights provisions ${ }^{51}$; their wide scope can unveil unpreceded fundamental subjective content.

Furthermore, it is relevant to mention Robert Alexy's conception of rights as principles and his concept of right as a whole; both seem to be critical elements to the

47 ALEXY, Robert. Teoría de los derechos fundamentales. 2.ed. Madrid: Centro de Estudios Políticos y Constitucionales, 2007, p. 381 ss/415 ss; PIEROTH, Bodo; SCHLINK, Bernhard. Grundrechte, Staatsrecht II, 11.ed., Heidelberg: C. F. Müller, 1995; MICHAEL, Lothar. Los derechos de igualdad como principios iusfundamentales. In: SIECKMANN, Jan-R.. (ed.) La teoría principialista de los derechos fundamentales: estudios sobre la teoría de los derechos fundamentales de Robert Alexy. Madrid: Marcial Pons, 2011, p. 137-143.

48 GRIMM, Dieter. The role of fundamental rights after sixty-five years of constitutional jurisprudence in Germany. International Journal of Constitutional Law, vol. 13, Issue 1, January 2015, Pages 9-29, https://doi. org/10.1093/icon/mov005.

49 For different understandings on the objective dimension, see ALEXY, Robert. Grundrecht als subjektive Rechte und als Objektive Normen. Der Staat, 29. Band, Heft 1, 1990, p. 49-68; BÖCKENFÖRDE, Ernst-Wolfgang. Grundrechte als Grundsatznormen. Der Staat (Zeitschrift für Staatslehre, öffentliches Recht und Verfassungsgeschicht). 29. Band. Berlin, Duncker und Humblot, 1990, p. 1-31.

50 This idea of deriving subjective advantage positions with fundamental content from objective norms is not new in the constitutional theory, although it is not free from controversy. It seems interesting that it also appears in international law, and even as controversial, as made clear with the following example presented by Catherine Brölmann and Christina Binder: "Finally, a particular category of interpretive questions is whether a treaty creates individual rights, even if not explicitly addressed to individuals in the way of a human rights treaty. A well-known subject of debate is Article 36 of the Convention on Consular Relations, according to which local authorities must notify all detained foreigners 'without delay' of their right to have their consulate informed of their detention. In Cornejo v County of San Diego and ors the Court held that this provision entailed no individual right." (BRÖLMANN, Catherine, BINDER, Christina. The law of treaties before domestic courts and human rights bodies. Amsterdam Law School Legal Studies Research Paper No. 2017-41 Amsterdam Center for International Law No. 2017-27.)

51 One can speak of broad interpretation or broad scope of rights (ALEXY, Robert. A theory of constitutional rights. Oxford: Oxford University Press, 2010, p. 201 ss). For an interesting approach specifically aimed at social and economic rights, see LEIJTEN Ingrid. Core socio-economic rights and the European Court of Human Rights. Cambridge: Cambridge, 2018, p. 98 ss. 
idea sustained is this paper. Because principles are optimization commands ${ }^{52}$, fundamental rights as principles command to be fulfilled in the maximum possible extent, considering the factual and normative circumstances. This conception is based on the comprehension of principles encompassing prima facie and definitive norms.

All these theoretical constructions make it possible, departing from a fundamental right explicitly positivized in the constitution, from provisions that enshrine general rights or even from general constitutional clauses, to ground the interpretative result which recognizes and justifies new fundamental subjective contents.

International law also plays an important role in the structural openness. There are prominent examples of constitutional provisions that command the interpretation of national law according to international norms and standards, which could result in updating the domestic rights system. Additionally, the practice of regional and international courts should not be neglected. It exposes the renewing influence wielded by international law in the domestic interpretation of both national and international law. In this scenario, international law emerges, beyond the existence of binding norms, as an interpretative guideline. In domestic case law, it is possible to find references to treaties (with or without legal force) to support particular interpretations of domestic law, as pointed out by Catherine Brölmann and Christina Binder ${ }^{53}$. Besides traditional international law, there are real speculations about an emerging global legal order which might be meaningful for the structural openness ${ }^{54}$.

At this point it is also relevant to consider the growing dialogue between several national, regional, and international courts ${ }^{55}$. This dialogue reveals cases of evident mutual influence in what is being called constitutional borrowing when concerning domestic constitutional courts ${ }^{56}$.

\footnotetext{
52 ALEXY, Robert. A theory of constitutional rights. Oxford: Oxford University Press, 2010, p. 47-48.

53 They even give an example: "Next to interpretation of binding treaty norms, courts may adopt an interpretive discourse and refer to treaties without legal force in the domestic legal order, in order to support and legitimize a particular reading of a domestic legal provision. One example of such 'treaty-conform interpretation' is the Englaro case mentioned above." (BRÖLMANN, Catherine, BINDER, Christina. The law of treaties before domestic courts and human rights bodies. Amsterdam Law School Legal Studies Research Paper No. 2017-41 Amsterdam Center for International Law No. 2017-27.)

54 See, among others, KRISCH, Nico. Global administrative law and the constitutional ambition. In: DOBNER, Petra; LOUGHLIN, Martin. The twilight of constitutionalism? Oxford: Oxford, 2012, p. 245-266; CASSESE, Sabino. La globalización jurídica. Madrid: Marcial Pons, 2006; TEUBNER, Gunther. Constitutional fragments: societal constitutionalism and globalization. Oxford: Oxford, 2012.

55 See NOLLKAEMPER, Andre, Conversations Among Courts: Domestic and International Adjudicators. In ALTER, Karin, ROMANO, Cesare, SHANY, Yuval (eds), Handbook of International Adjudication (OUP 2013, Forthcoming), Amsterdam Law School Research Paper No. 2013-30, Amsterdam Center for International Law No. 2013-08, Available at SSRN: https://ssrn.com/abstract=2270565 or http://dx.doi.org/10.2139/ssrn.2270565; MAUS, Didier. Le recours aux précédents étrangers et le dialogue des cours constituionnelles. Revue française de droit constitutionnel. Paris, n. 80, oct., 2009, p. 675-696.
}

56 EPSTEIN, Lee; KNIGHT, Jack. Constitutional borrowing and non borrowing. International journal of constitutional law. New York, v. 1, n. 2, ap. 2003, p. 196-223 GREWE, Constance. Les influences du droit allemand 
Finally, constitutional mutation or constitutional evolutive interpretation must be addressed under the structural openness. New or renewed fundamental content can be construed as a result of the evolving meaning of constitutional provisions. The interpretation process of constitutional provisions is dynamic and can lead to new interpretive outcomes without changing the textual wording, without constitutional amendment procedures ${ }^{57}$. This evolutive interpretation unfolds namely in the practice of constitutional courts.

Judicial application of law, either in common law and or civil law systems, especially developed by constitutional courts, which create precedents or customary judicial law, should be preferably located within the interpretative field. The decisions that result from the application of law do not go beyond interpretation; they do not ordinarily create new norms ${ }^{58}$.

For its turn, the concretization of constitutional fundamental rights norms through further development by ordinary legislation appears to be somehow different. Because of the nature of constitutional provisions and their normative hierarchy, supplementary legislative development is often required to make constitutional norms applicable and effective. This is particularly important in the domain of fundamental rights. These rights claim legislative concretization, which can amplify fundamental contents by rendering them specifically established and clarifying the states duties they impose. The legislative concretization of fundamental rights constitutional norms goes beyond interpretation and deliver new ordinary law norms.

To a certain extent it is viable to differentiate openness of the fundamental rights system through interpretation and through the creation of norms. In other words, it is possible to distinguish between the recognition of implicit fundamental "new" content without constitutional amendment or legislative change and the addition of new fundamental content through the creation of new constitutional or ordinary legal

des droits fondamentaux sur le droit français: le rôle médiateur de la jurisprudence de la Cour Européenne des Droits de l'Homme. Révue universelle des droits de I'homme, 2004, oct., v. 16, n. 1-4, p. 26-32; ROSENKRANTZ, Carlos F. Against borrowings and other nonauthoritative uses of foreign law. Constitutional borrowing and non borrowing. International journal of constitutional law, New York, v. 1, n. 2, ap. 2003, p. 269-295.

For an interesting approach on constitutional borrowing, with special attention to the use of proportionality, see ANDRADE NETO, João. Borrowing justification for proportionality: on the influence of the principles theory in Brazil. Springer, 2018.

57 Interpretation in international law may not be exactly the same as in constitutional law, but, besides specificities, the interpretative enterprise in both fields holds important common aspects. In this context, it is interesting to quote Ingo Venzke on the possibility of changing in meaning without changing in the textual provision: "Be that as it may, an interpretation does not stop being an interpretation when it modifies the law." (VENZKE, Ingo, Authoritative Interpretation (October 11, 2018) In: Max Planck Encyclopedia of International Procedural Law; Amsterdam Law School Research Paper No. 2018-28; Amsterdam Center for International Law No. 2018-10. Available at SSRN: https://ssrn.com/abstract=3264566). See also JELLINEK, Georg. Reforma e mutación de la constitución. Madrid: Centro de Estudios Constitucionales, 1991.

58 PONTHOREAU, Marie-Claire. La reconnaisance des droits non-écrits par les cours constitutuionnelles italienne et française: essai sur le pouvoir créateur du juge constitutionnel. Paris: Economica, 1994. 
norms. Having presented how the structural openness can operate, it becomes clear it mainly arises on the interpretative level. It is important to note, however, that the judicial application of fundamental rights norms and the legislative concretization of fundamental rights might show that this differentiation is not absolute; the line between interpretation and legal creation can be rather blurred.

Finally, it is important to notice that the assertion of an implicit principle that commands the updating of the fundamental rights system influences the structural openness. Indeterminacy and the open texture of law are a given and cannot be entirely avoided. Nonetheless, these phenomena do not provide a normative guidance, an imposition on how structural openness of law should unfold. The principle of openness, if accepted as here advocated, lends a goal to the interpretation of fundamental rights provisions. The principle guides the interpretation, through indeterminacy and open texture, in the direction of actualizing and updating the norms and the system in favour of human dignity.

\subsection{The principle of openness}

One of the core arguments developed in this paper is that there is an implicit principle of openness which commands state powers (branches) to implement a constant update of the fundamental rights system in order to guarantee full respect to human dignity through evolving historical circumstances. As (an implicit) a legal norm, this principle imposes a renewing interpretation of the already existing fundamental rights norms (and other relevant norms of the system) as well as the integration, creation, and enactment of new norms. The openness principle can, reversely, also impose some restrictive interpretation or normative restrictive changes as far as these can be required by the system as a whole.

This principle of openness cannot be identified with constitutional explicit open clauses; it is a broader principle whose regulation capacity goes way beyond what is commanded by specific open clauses $^{59}$.

Considering that such an openness principle is not an explicitly formulated norm in concrete constitutions, it requires an argumentative path able to anchor it in

\footnotetext{
59 The implicit principle of openness can be seen as multifunctional, since it can possibly: warrant the central position of human dignity in the constitutional system; warrant and promote the dynamic respect for human dignity; warrant the structuring function of the human rights system within the constitutional system; warrant the unity of the constitution; preserve the constitution through its capacity to adapt; impose the permanent update of the fundamental rights system; impose a comprehensive interpretation of the fundamental rights norms; impose a favourable interpretation towards the recognition of implicit rights; warrant the legitimacy of judicial decisions which recognize implicit rights or deduct rights from constitutional norms; impose and legitimate the updating interpretation of the fundamental rights system through constitutional evolutive interpretation; impose restrictive or accommodative modifications in the system if mandatory to update the system in the service of human dignity; impose the openness of national law towards international law.
} 
explicit existing provisions. The following directly established provisions and norms offer enough legal foundation to affirm that the principle is a derivative norm: constitutional provisions concerning human dignity; the democratic principle; an explicit open clause (if present in the constitution); constitutional provisions on the reception of international norms and interpretation of domestic law according to international norms and standards; constitutional provisions specifically concerning fundamental rights; constitutional provisions that grant competence to constitutional amendment and legislative activity. Maybe it would be possible, in the European Union, to present an additional normative foundation to the principle of openness: the provisions which discipline the necessary interrelations between different fundamental rights regimes in order to achieve an adequate level of integration ${ }^{60}$.

All these norms and explicit constitutional provisions deliver enough normative foundation to anchor the implicit principle of openness, which emerges as a warranting element of the fundamental rights system of the constitutional state. In other words, they enable to affirm the principle as part of the domestic rights systems. The core normative content of the principle was exposed above and is mandatory either to interpretation or to other state activities, especially the legislative one.

Openness is, therefore, threefold: structural, commanded by a principle and imposed by international law. Furthermore, openness operates on two levels, interpretation and the creation of norms. Before exposing the last façade of openness as imposed by international law is seems essential to address how it operates on the level of normative creation.

\subsection{Openness to receive new norms}

The openness that operates beyond the interpretative level and means aggregating new normative elements to the system may bring these new fundamental contents inside through various doors.

A well-known door is represented by the explicit open clauses present in many contemporaneous constitutions. The existence of an explicit constitutional provision enshrining an open clause is a specific precipitation of the broader principle of openness and can manifest in various concrete ways in different constitutional provisions. Such provisions can be found in the Brazilian Constitution (Art 5, paragraph 2: The rights and guarantees expressed In this Constitution do not exclude others deriving from the regime and from the principles adopted by it, or from the International treaties In which the Federative Republic of Brazil is a party.), in the IX Amendment to the Constitution of

60 ECKES, Christina. Integrated rights protection in the European and International Context: some reflections about limits and consequences. In GOVAERE, I., GARBEN, S. (Eds.). Interfaces between European and International Law (pp. 101-124). (Modern Studies in European Law; Vol. 89). Oxford: Hart Publishing, 2019. https://doi. org/10.5040/9781509923410). 
the United States of America (The enumeration In the Constitution, of certaln rights, shall not be construed to deny or disparage others retalned by the people. ${ }^{61}$, in the Portuguese Constitution (Art. 16. n. 1: The fundamental rights enshrlned In the Constitution shall not exclude any others set out In applicable International laws and legal rules.), to quote only a few examples.

It seems clear that an explicit open clause can also have an impact on the interpretative level, since unwritten rights can be implicit, deriving from existing constitutional provisions. Nonetheless, explicit open clauses exercise a more central role in the openness of the system beyond the interpretative level or even in the blurred space between interpretation and new normative content creation and enactment. This is the terrain where open clauses make it irrefutable that new content ought to be accepted into the system.

This is no neutral data for the argumentative process in favour of opening the system towards welcoming new fundamental content. The importance of such an explicit open clause should not be undermined; it makes the open nature of the system irrefutable. In doubtful situations, an open clause hinders the possibility of denying the acceptance of new fundamental content into a specific rights system.

The welcoming of new fundamental content to the system can happen, depending on the specificities of the concrete constitutional system concerned, through the reception of international law norms, through constitutional amendment and through the enactment of new legislative norms. All these phenomena are here understood falling under the regulative field of the implicit principle of openness.

It is common that constitutions, besides or not to an explicit broad open clause, enshrine specific open clauses towards international law. Many constitutions stipulate the reception of international law norms that can convey new rights, norms on interpretation, norms on legal remedies and even norms on rights restrictions ${ }^{62}$.

61 MASSEY, Calvin R.. Silent rights: the ninth amendment and the Constitution's unenumerated rights. Philadelphia: Temple University, 1995; BARNETT, Randy E.. Reconceiving the ninth amendment. 74 Cornell Law Review, 1, 1988-1989, p. 1-42; BARNETT, Randy E..Who's afraid of unenumerated rights. University of Pennsylvania Journal of Constitutional Law, 1, 2006-2007, p. 1-22; DWORKIN, Ronald. Unenumerated Rights: whether and how Roe should be overruled. The University of Chicago Law Review, 59.1992, p. 381-432.

62 See the example of the Brazilian Constitution: "Art. 5, paragraph 3: International human rights treaties and conventions which are approved in each house of the national congress, in two rounds of voting, by three fifths of the votes of the respective members shall be equivalent to constitutional amendments." In the Portuguese Constitution there is this provision: "Art 16. n. 2: The constitutional precepts concerning fundamental rights must be interpreted and completed in harmony with the Universal Declaration of Human Rights."

on open clauses in Latin American Constitutions, see BREWER-CARÍAS, Allan. Constitutional protection of human rights in Latin America. Cambridge, 2009, p. 21 ss; NETTO, Luísa Cristina Pinto e. A abertura do sistema de direitos fundamentais do Estado Constitucional. Curitiba: Íthala, 2016.

Maybe the Dutch Constitution should receive special attention. Although much has been written about its openness towards international law, because of its explicit provision on the matter (Article 93: "Provisions of treaties and of resolutions by international institutions which may be binding on all persons by virtue of their contents shall become binding after they have been published."), a punctual approach in this specific fundamental rights scenario might be particularly interesting. 
Another door for new fundamental content is the traditional process of constitutional amendment, well-known either in rigid or in flexible constitutional models, which leads, within their idiosyncrasies, to accommodating new content in the fundamental rights system.

The constitutional amendment relates to the norm of openness but requires specific attention. The presence of constitutional provisions disciplining constitutional amendment tries to parameter the tension between the necessity of having basic norms settled and the necessity of regularly exercising democratic power to respond to historical changes. The implicit principle of openness commands the update of the system to face new challenges posed to human dignity. Nonetheless, there are legal obstacles to assert an obligation to amend the constitution. The competence or the possibility to do so might be disciplined in the system, but its exercise rests upon democratic will within the constitutional order.

The fundamental rights system participates in the architecture of the constitutional identity and must, therefore, maintain its core meaning; core provisions represent substantial limits on constitutional amendment. Notwithstanding, there can be, to a certain extent, restrictive constitutional amendments concerning fundamental rights. What is important to note is that constitutional amendment is a proper way of updating the fundamental rights system and that it happens beyond interpretation, through textual provision modification.

Considering the general nature of constitutional fundamental rights provisions and the various duties they necessarily impose on state, the effectiveness of fundamental rights depends for a great extent on state normative and concrete activities. Constitutional fundamental rights norms often require further legislative development. Ordinary law provisions may carry new fundamental content capable of claiming compensatory constitutionalization.

\subsection{Openness imposed by international law}

In our kaleidoscopic multilevel legal world, the interaction between various legal orders seems unavoidable ${ }^{63}$. The mutual influence exercised by international law, global law and domestic constitutional law (it seems more appropriate to think of constitutional laws in order to emphasize the multitude of legal domestic orders that interact), has an appealing impact on rights and on the openness of the fundamental rights

63 The expression kaleidoscopic was borrowed from Edith Brown Weiss (WEISS, Edith Brown. Intergenerational Equity in a Kaleidoscopic World, Environmental Policy and Law, vol. 49, no. 1, pp. 3-11, 2019. $<$ https://content.iospress.com/download/environmental-policy-and-law/epl190115?id=environmental-policy-and-law\%2Fepl190115> accessed 21 January 2020; WEISS, Edith Brown. International Law in a Kaleidoscopic World (2011). Georgetown Law Faculty Publications and Other Works. 1622. https://scholarship.law. georgetown.edu/facpub/1622). 
system. This phenomenon operates either through interpretation as through adding new norms to the system; the different ways of openness relate and strengthen each other.

It seems important to note, as pointed out by Christina Eckes, when writing on human rights protection in the European and international scenario, that human rights constitute a special case in the interaction between different legal spheres ${ }^{64}$.

A first open door in the international law field is the recognition of an International law of human rights ${ }^{65}$. It is somewhat controversial but still affirmed that some international norms on human rights hold jus cogens nature ${ }^{66}$. The reserved state domain suffers an erosion when it comes to rights; beyond the field of autonomous commitments, the set of jus cogens norms amounts, imposing itself heteronomously, and does no longer simply fall into states' sovereign decision terrain.

The absence of international institutions and courts to enforce these norms represent relevant theoretical and practical problems to their acceptance. However, this does not preclude the possibility and importance of cogitating of International human rights law and approaching it as a significant way of openness of the domestic fundamental rights systems.

64 Christina Eckes wrote: "Human rights are a special case when it comes to the interaction of different legal spheres. I would go as far as claiming that fundamental rights constitute the most difficult area when pondering questions of resilience, autonomy and porosity of one legal sphere vis-à-vis another. The following five substantive reasons support this position. They also explain why institutionally rights have proven so problematic within the history of EU integration." For these five reasons and further development, see ECKES, Christina. Integrated rights protection in the European and International Context: some reflections about limits and consequences. In GOVAERE, I., GARBEN, S. (Eds.). Interfaces between European and International Law (pp. 101-124). (Modern Studies in European Law; Vol. 89). Oxford: Hart Publishing, 2019. https://doi.org/10.5040/97815099234100.

65 TRINDADE, Antônio Augusto Cançado. Tratado de direito internacional dos direitos humanos. v. I. Porto Alegre: Sergio Antonio Fabris, 1999; KÄLIN, Walter; KÜNZLI, Jörg. The law of international human rights protection. Oxford: Oxford, 2009.

66 Discussing this problematic from different perspectives, see, among others, CRIDDLE, Evan; FOX-DECENT, Evan. Fiduciaries of humanity: how international law constitutes authority. Oxford scholarship online. 2016 ( DOI:10.1093/acprof:oso/9780199397921.001.0001); TASIOULAS, John. Custom, jus cogens, and human rights. In: BRADLEY, Curtis A. ed. Custom's future: international law in a changing world. Cambridge University Press, Forthcoming, < https://papers.ssrn.com/sol3/papers.cfm?abstract_id=2581763\&download=yes > acessed 21 January 2020; PETERS, Anne. 'Compensatory constitutionalism: the function and potential of fundamental international norms and structures', 19 Leiden journal of international law (2006); BIANCHI, Andrea. Human rights and the magic of jus cogens. The European Journal of International Law, Vol. 19 no. 3 ๑ EJIL 2008; PARKER, Karen. Jus Cogens: compelling the law of human rights. Hastings Int'l \& Comp. L. Rev, v. 12, n. 2, p. 411-463, 1989.; DE WET, Erika. The emergence of international and regional value systems as a manifestation of the emerging international constitutional order. Leiden Journal of International Law, 2006, n. 19, p. 611-632; DE WET, Erika. The emerging international constitutional order: the implications of hierarchy in international law for the coherence and legitimacy of international decision-making. PER/PLJ, 2007, v. 10, n. 2, p. 21-46; DE WET, Erika. The international constitutional order. International and Comparative Law Quarterly, 2006, jan., v. 55, p. 51-76; DE WET, Erika. The prohibition of torture as an international norm of jus cogens and its implications for national and costumary law. European Journal of International Law, 2004, v. 15, n. 1, p. 97-121; BAPTISTA, Eduardo Correia. Ius cogens em direito internacional. Lisboa: Lex, 1997. 
Besides this heteronomous content which imposes itself to states, international law conveys substantial new fundamental content to the fundamental rights system through self-commitment of states. Many constitutions, as mentioned above, discipline the integration of international norms within the domestic legal order, which would fall within the traditional international public law. States commit themselves through international law binding instruments which bring new content into their domestic rights systems.

Furthermore, the emergence of a global legal order and global or transnational constitutionalism also comes into play; there is an attempt to construct a global law which goes beyond the traditional public international law ${ }^{67}$. Many scholars write about constitutionalism beyond the state; in these discussions, human rights take an important position as they are crucial in any constitutionalizing movement of the global space. Despite all difficulties faced by such a construction, it seems possible to speak of an emerging global values system: a set of principles and moral norms vehiculated by legal means in which human dignity, human rights and fair procedures stand in the very centre. In such a scenario, states do not lose their role towards rights, but state sovereignty claims are revisited ${ }^{68}$.

On the one hand, the legal interactions here addressed can lead to new content being integrated into the fundamental rights system of a constitutional state as new norms. On the other hand, interpretative operations based on these interactions are no less capable of fertilizing the system. It is important to highlight that the influence is mutual; international law influences domestic law but is in its turn also significantly enriched by national jurisdictions and legal contributions.

67 PETERS, Anne. Membership in the global constitutional community. In: KLABBERS, Jan; PETERS, Anne; ULFSTEIN, Geir. The constitutionalization of international law. Oxford: oxford, 2009, p. 153-262. With different points of view on these matters, see: CASSESE, Sabino. La globalización jurídica. Madrid: Marcial Pons, 2006; TEUBER, Gunther. Fragmented foundations: societal constitutionalism beyond the national state. In: DOBNER, Petra; LOUGHLIN, Martin. The twilight of constitutionalism? Oxford: Oxford, 2012, p. 327-341; DOBNER, Petra. More law, less democracy?: democracy and transnational constitutionalism. In: DOBNER, Petra; LOUGHLIN, Martin. The twilight of constitutionalism? Oxford: Oxford, 2012, p. 141-161; TEUBNER, Gunther. Constitutional fragments: societal constitutionalism and globalization. Oxford: Oxford, 2012; LOUGHLIN, Martin. What is constitutionalisation? In: DOBNER, Petra; LOUGHLIN, Martin. The twilight of constitutionalism? Oxford: Oxford, 2012, p. 47-69; KUMM, Mattias. The legitimacy of international law: a constitutionalist framework of analysis. The European Journal of International law, 2004, v. 15, n. 5, p. 907-931; GRIMM, Dieter. The achievement of constitutionalism and its prospects in a changed world. In: DOBNER, Petra; LOUGHLIN, Martin. The twilight of constitutionalism? Oxford: Oxford, 2012, p. 3-22; KUMM, Mattias. The best of times and the worst of times: between constitutional triumphalism and nostalgia. In: DOBNER, Petra; LOUGHLIN, Martin. The twilight of constitutionalism? Oxford: Oxford, 2012, p. 201-219; KRISCH, Nico. Global administrative law and the constitutional ambition. In: DOBNER, Petra; LOUGHLIN, Martin. The twilight of constitutionalism? Oxford: Oxford, 2012, p. 245-266. KRISCH, Nico. Beyond constitutionalism: the pluralist structure of postnational law. Oxford: Oxford, 2010.

68 PETERS, Anne. Humanity as the $A$ and $\Omega$ of sovereignty. The European Journal of International Law, 2009 , v. 20, n. 3, p. 513-544. 
At this point, the open nature of the fundamental rights system of the constitutional state as a general theoretical conception has been presented in its core ideas. It is guided by the goal of providing human dignity with updated and adequate protection and means to self-development. Openness is unavoidable. Nonetheless, openness as stated, claims for boundaries, which will be addressed in the following section.

\section{OPENNESS AND CLOSURE OF THE FUNDAMENTAL RIGHTS SYS- TEM - CRITERIA FOR APPROACHING SUBSTANTIAL FUNDA- MENTALITY}

The argumentation developed so far focused on the systematic organization of fundamental rights in domestic constitutions and on the inherent open nature of these rights systems. The central idea is that the grounding legal norm of human dignity claims updated protection and promotion to face evolving challenges and threats. This underlying assumption reinforces the importance of fundamental rights and, consequently, all the theoretical construction aims to strengthen its concept, enforceability, and effectiveness.

In this context, respecting these very central premises, the acknowledgement that fundamental rights are powerful legal means to protect and promote human dignity is crucial. Nonetheless, it does not follow that an endless expansion of rights leads to a better protection for human dignity. An artificial proliferation of rights can have deleterious effects on the domestic separation of powers, on the capacity of states to guarantee rights, on the normative force of rights.

To face an alleged rights overreach and its consequences and guarantee the role of rights as effective legal means implying feasible obligations, it is vital to offer theoretical foundations and boundaries to the conception of an open rights system. The goal is to prevent the denaturation and weakening of the concept of human and fundamental rights ${ }^{69}$.

\footnotetext{
69 The construction advanced above focused on the fundamental rights system; it offered a theoretical and general approach to rights systems enshrined in domestic constitutions. Some core ideas can be translated beyond the state as soon as the necessary adaptations to address a general human rights system are made. Specially the idea of interpretative openness seems adequate and useful. It does not appear impossible, however, to also cogitate of openness to new content on human rights considering the broader panorama of international law sources. In addition, one can think of openness as a consequence of the interaction with domestic legal orders. Anyway, the particularities of international law must not be neglected and lead to the necessity of further specific development on the openness of the human rights system. There is no such instrument as a global constitution, no such courts. Besides, the legal order beyond the state is fragmentated and populated by a series of various actors. These clarifications having been made, it is relevant to assign that the phenomenon of an alleged rights overreach can be regarded either domestically either internationally and in this aspect it seems that a joint approach is possible. The argumentation hereafter will focus mainly in the domestic arena, but can be again translated, mutatis mutandis, to the global arena.
} 
Therefore, this paper proposes to take a further step. Beyond asserting the open character of the fundamental rights system, it also aims to explore the consequences of this openness upon the constitutional system and upon the rights system itself. Hereafter, an attempt to strike an adequate balance between openness and closure of the rights system is made ${ }^{70}$.

\subsection{Consequences of the openness}

The assumption that the fundamental rights system of the constitutional state holds an open nature forcibly delivers substantial consequences for the broader legal system of this state. The first pillar of this state model where these consequences appear is the separation of powers; openness implies an active role of the judiciary, especially of constitutional courts.

The conception of structural openness and the multitude of norms with a nature of principles, namely the fundamental rights, have a clear impact on the interpretation field. The judiciary is called to give the last word on interpretation, bringing to light the implicit rights, the unenumerated rights, the various subjective positions included in a fundamental right positivized as a principle. In this process the judiciary should present and justify implicit, derivative norms. This circumstance enhances the judicial control competences concerning legislative activity ${ }^{71}$. The judiciary cannot flee from this task but cannot, on the other hand, trespass its boundaries and become legislator. This would represent a disequilibrium in the division of functions and could also create burdens to executive action without direct democratic foundation.

Apart from the questions which arise from the importance given to interpretation, it seems undeniable that "new" rights always impose new burdens on all state powers. One often thinks of the classical social rights, which more clearly demand positive state action. Nonetheless, one should also consider some very actual "broad" rights, such as, for example, the alleged right to development ${ }^{72}$. Stephan Schill calls

\footnotetext{
70 Hurst Hannun writes: "Attempting to regulate ever more narrow slices of life under ever more diverse circumstances through promoting new human rights runs a serious risk of undermining both the legitimacy of human rights and their universality. The result may be to simply expand the number of rights that are routinely ignored rather than to bring real help to those whose rights, no matter how narrowly construed, are already being violated." (HANNUM, Hurst. Rescuing human rights: a radically moderate approach. Cambridge, Cambridge University Press, 2019, p. 79)

71 For an interesting discussion departing from a concrete case, see: BURGERS, Laura; STAAL, Tim Climate action as positive human rights obligation: the appeals judgment in Urgenda v the Netherlands. In WESSEL, Ramses A; WERNER, Wouter; BOUTIN, Bérénice (Eds.) Netherlands Yearbook of International Law 2018, T.M.C. Asser Press, forthcoming in spring 2019. Centre for the Study of European Contract Law Working Paper Series No. 2019-01.

See also, KUMM, Mattias. Alexy's theory of constitutional rights and the problem of judicial review. In: KLATT, Matthias (ed.). Institutionalized reason: the jurisprudence of Robert Alexy. Oxford: Oxford, 2012, p. 201-217.

72 For an interesting approach on the right to development, see BALDE, Aua. O direito ao desenvolvimento como um direito fundamental. In: African human rights yearbook. V 3. Pretoria: Pretoria University Press, 2019, p. 49-71.
} 
the attention that such a right demands governance structures because "successful development depends on function Ing political and economic structures"73. Yvonne Donders also makes the broad spectrum of this right evident, when explaining its meaning and content; the right to development entails that "people are entitled to participate In, contribute to and enjoy economic, social, cultural, political development In which all human rights can be fully realized"74. Considering that fundamental or human rights impose significant burdens on states, it is not feasible to envisage an always escalating bundle of new rights and disregard states obligations, budget, organization and procedures ${ }^{75}$.

Other consequences of the openness also challenge the constitutional system. The openness of the rights system culminates in operating a compensatory constitutionalization of rights not enshrined in constitutional provisions, either not explicitly formulated but capable of being arguably implicit or new rights conveyed by ordinary law or international law provisions. Ordinary norms or international norms that establish rights are lifted to a constitutional level, are constitutionalized. The assumption that these rights (especially the ones established by ordinary law provisions), which are not formally constitutional, participate in the substantive constitution presents the peril of subverting the normative hierarchy and depleting the superiority of constitutional norms.

This is not the opportunity to deepen and discuss in detail all possible consequences of the openness of the fundamental rights system for the constitutional system. It is important to acknowledge them in an attempt to draft a broad scenario, but the focus in this paper must lay on the rights system itself.

Within a wider possible range of consequences of openness for the fundamental rights system itself, the following must be highlighted: necessity of defining the legal protection regime of the rights; danger of uncontrolled enhancing of the so-called fundamental rights weakening their significance and importance; increased risk of conflict between rights; necessity of protection against backsliding; necessity of criteria for assessing the substantial fundamentality of "new" rights.

73 SCHILL, Stephan; TAMS, Christian J., HOFMANN, Rainer. International investment law and development: friends or foes? (2015). In SCHILL, Stephan; TAMS, Christian J., HOFMANN, Rainer (eds.). International investment law and development: bridging the gap (Cheltenham: Edward Elgar Publishing, 2015) 3-42. DOI: 10.4337/9781784711351.00008, Amsterdam Law School Research Paper No. 2017-26, Amsterdam Center for International Law No. 2017-22, Available at SSRN: https://ssrn.com/abstract=2934251.

74 DONDERS, Yvonne; LAAKSONEN, Annamari. Finding Ways to Measure the Cultural Dimension of Human Rights and Development (November 9, 2009). Available at SSRN: https://ssrn.com/abstract=1657837 or http:// dx.doi.org/10.2139/ssrn.1657837

75 In my professional experience as state attorney for the state of Minas Gerais in Brazil, I have experienced this aspect in the everyday practical legal activity. In Brazil, under the Constitution of 1988, an ever-growing number of lawsuits against states and federal government has taken place, with various demands on rights enforcement, especially in the field of the right to health. In this scenario, the judiciary becomes central, frequently determining that the government (the executive branch) must provide remedies and medical treatment with substantive consequences on public health policies and on public budget and expenditure. 
A specific question concerning the compensatory constitutionalization of rights is their regime; which should be the legal regime of new, unwritten, or implicit rights? The first idea is that the regime of compensatory constitutionalized rights ought to be the same as the formal constitutional rights. Due to their substantial content, these "new" rights ought to be granted constitutional status, ought to receive the legal protection aimed at the formally enshrined rights. The underlying reason to constitutionalize rights is to guarantee them the protection offered by the warranting elements of the rights system.

The risk of weakening the constitutional normativity mentioned above appears as a specific risk of weakening the fundamental rights legal force. A hyperbolized "creation" or acceptance of new fundamental rights could unfold into a rights overreach or artificial proliferation. Openness could become a process of "panjusfundamentalization", i.e., regarding every possible human claim or every state duty or obligation as a fundamental right. Since the state cannot cope with the burden brought by all these alleged fundamental rights, their effectiveness is in danger as well as the enforcement of the constitution. To turn the eyes again towards state powers, an overreaching compensatory constitutionalization of rights can lead to weakening constitutional normativity.

It seems relevant to approach "panjusfundamentalization" because it may empty the significance of fundamental rights and lead to deleterious effects on fundamental rights and on the constitutional system itself. It is possible to speculate of a "panjusfundamentalization" phenomenon (i) regarding the holder/titularity of the rights - artificial broadening of the conception of the right holder, advocating rights for legal persons, for animals, for the environment; (ii) regarding the protected good or content of the rights - subjectivizing contents that have an objective nature or a meta-individual common good, e.g., a right to legality, a right to environment, a right to a good administration, a right to a corruption-free administration, a right to transparency ${ }^{76}$; (iii) regarding rights addressees - rights addressing not only state powers, but private actors and individuals.

It is important to notice that asserting or questioning if some content should receive legal protection under the framework of fundamental or human rights and answering that it should not, does not mean these goods or values do not deserve legal protection. It means that another juridical framework might be more suitable. One example may clarify the issue. It is common to assume a rights-based approach to corruption in developing or underdeveloped countries, relating rights insufficient

\footnotetext{
76 With a similar approach see: "The first is substantive overreach. This relates to what we take to be human rights. There is a persistent tendency to present more and more political demands as human rights, but on very dubious grounds." (TASIOULAS, John. Are human rights taking over the space once occupied by politics? Newstatesmen (26, August, 2019). (<https://www.newstatesman.com/2019/08/are-human-rights-takingover-space-once-occupied-politics> accessed 07.02.2020).
} 
enforcement with corruption and regarding corruption as a violation against rights; a right to a good and probe administration is often called upon ${ }^{77}$. This exemplifies "panjusfundamentalization" or the now so-called rights overreach. There might be a more suitable legal framework to fight against corruption than labelling it within the rights discourse $^{78}$.

Because fundamental and human rights stand central in the legal orders (domestic and beyond the state) and touch axial issues that regard state, community, and the individual, they intertwine with almost every pungent political decision. A tendency to draw on rights framework to address these decisions and try to solve political, economic and social acute problems is understandable. Rights have been standing more and more in the centre of legal and political discussions after the Second World War. It is appealing to think that rights will offer the answer to climate and environment problems, that they will eventually help us through the dilemmas brought about by technology and science in a world still marked by enormous inequalities and undiagnosed risks. Nonetheless, rights legal framework might not be capable neither suitable for these challenges; some issues demand different approaches in the political and economic arena ${ }^{79}$.

These considerations point to a steady defence of fundamental and human rights, but at the same time, to a prudent and conscious approach, not disregarding the necessity of caution towards a "panjusfundamentalization" or overreach phenomenon. The peril of not recalibrating the scope of rights discourse and legal practice, in order to strengthen their concept and normative force, might be, in reverse, strengthening scepticism and populist onslaughts against these very rights ${ }^{80}$.

From another perspective, light must be shed on the fact that rights also have an impact in private relations and that an artificial proliferation of rights can have as a

\footnotetext{
77 The Charter of Fundamental Rights of the European Union establishes a "right to good administration" in its article 41. For an interesting approach, see PETERS, Anne. Corruption as a Violation of International Human Rights, European Journal of International Law, vol. 29, n. 4, p. 1251-1287, nov. 2018.

78 PETERS, Anne. Corruption as a Violation of International Human Rights, European Journal of International Law, vol. 29, n. 4, p. 1251-1287, nov. 2018.

79 For an interesting approach on these issues, see HANNUM, Hurst. Rescuing human rights: a radically moderate approach. Cambridge, Cambridge University Press, 2019; TASIOULAS, John. Are human rights taking over the space once occupied by politics? Newstatesmen (26, August, 2019). (<https://www.newstatesman. com/2019/08/are-human-rights-taking-over-space-once-occupied-politics $>$ accessed 07.02.2020).

${ }^{80}$ In this regard: "Often, growing scepticism about human rights is interpreted as a 'populist backlash'. Recall the threat by then US presidential candidate Donald Trump to bring back 'a hell of a lot worse than waterboarding' for suspected terrorists, or Brazilian President Jair Bolsonaro's dismissal of human rights as 'manure for rascals' 'rascals' designating indigenous people, the criminally accused, and members of the LBGTQ community." (TASIOULAS, John. Are human rights taking over the space once occupied by politics? Newstatesmen (26, August, 2019). (<https://www.newstatesman.com/2019/08/are-human-rights-taking-over-space-once-occupied-politics > accessed 07.02.2020).
} 
side effect a compression in freedom, delivering an opposite legal effect than expected. The horizontal efficacy of fundamental rights is of great importance but requires caution to identify the power relations suited for its application.

Besides that, in the fundamental rights field conflict is not an unexpected problem that demands a definitive solution, it is a constant challenge which claims to be permanently managed. Conflicts between fundamental rights and between fundamental rights and other constitutionally positivized values or goals are inherent and unavoidable. Even though this is a well-accepted aspect ${ }^{81}$, a rights proliferation might flow into an overarching multitude of conflicts with a negative effect on rights.

At this point, it is relevant to notice that the affirmation of the open character of the fundamental rights system implicates its mobility not only to expand its content but also to evolve through restrictive changes concerning specific rights. These restrictions can derive from new interactions between rights and between rights and norms that protect other constitutionalized values and goals. New rights might ask for abstract restriction upon existing rights; past and present expansive changes may lead to the future need of restrictive changes in the system. The resistance capacity of rights comes into play: is it possible to speculate about a prohibition of regression or backsliding of rights protection?

In recent years it became popular in the field of fundamental rights, especially social rights, to discuss the possibility of backsliding, of regression of rights legislative concretization and implementation. Scholarly relevant material appeared in some contexts defending the idea that once rights had been granted some level of normative concretization assuring their effectiveness, it would become forbidden to eliminate this legislative concretization. This prohibition has been built into an implicit constitutional principle, which, despite being controversial, can be reasonably justified and normatively anchored ${ }^{82}$. In fact, the very normative force of fundamental rights norms as constitutional provisions can ground their resistance ability against the pure elimination of legislative norms necessary to assure their effectiveness.

Considering that most of the thinkable updating modifications in the system are expansive ones and that conflicts involving rights and other constitutional goals are unavoidable, an absolute prohibition of regression is not feasible. Nonetheless, regres-

81 DONDERS, Yvonne. Towards a right to cultural identity?. Cambridge: Intersentia, 2002; DONDERS, Yvonne. Cultural Rights in International Human Rights Law: From Controversy to Celebration (June 26, 2020). published in: Japanese Yearbook of International Law ("Cultural Rights in International Human Rights Law: From Controversy to Celebration", Japanese Yearbook of International Law, Vol. 62 (2019) International Law Association of Japan (February 2020), pp. 61-84.), Amsterdam Law School Research Paper No. 2020-35, Amsterdam Center for International Law No. 2020-13, Available at SSRN: https://ssrn.com/abstract=3635993.

82 NETTO, Luísa Cristina Pinto e. O princípio de proibição de retrocesso social. Porto Alegre: Livraria do Advogado, 2010. 
sive measures must undergo strict control in order to be constitutional and adequate to the fundamental rights system. A heavy argumentative burden weighs on regressive changes. Firstly, it is essential to distinguish between concrete restrictive measures on fundamental rights when in conflict situations and abstract restrictive normative modifications on the constitutional or legislative level. The former indicates a concrete conflict in a one case ruling. The latter means precluding norms from the system. The restrictions approached here and limited by a prohibition of regression are restrictions on the abstract level, i.e., restrictions that mean stepping back on the concretization and effectiveness of rights by suppressing fundamental normative content of the legal system. These abstract restrictions must be proportionate and constitutionally acceptable ${ }^{83}$.

Despite the seriousness of the questions and normative problems briefly presented as consequences of the openness, they ought to coexist with the assumption - made in this paper - that the enumerated rights as a static and immobile set of rights are not enough to offer the legal protection and promotion required by human dignity. This conclusion is followed by the idea that the system should not be closed and static; it is inherently open and dynamic. Openness is, at the same time, a necessity concerning the protection required by human dignity and an inevitable consequence of the open texture of law. Openness is unwavering; nonetheless, the problems pointed claim to be managed, the system cannot expand limitless neither can it expand at the cost of its elements or at the cost of the constitutional normativity. Openness must coexist with some closure in order to preserve the system identity and to face the problems briefly presented.

Conceiving openness as an implicit principle provides relevant theoretical tools to face its own limits. Principles, as optimization commands, can collide with each other and demand a normative solution in which one principle overweighs other(s) without expunging the colliding principle(s) from the system. Departing from the application of the principle of openness, the critical aspect of advancing the conditions in which new rights should be accepted into the rights system rests on disclosing their substantial fundamentality. The other way round, the presence of substantial fundamentality identifies the conditions of application of the principle of openness; it unlocks the door to compensatory constitutionalization. Adequate criteria are required to reveal substantial fundamentality.

83 NETTO, Luísa Cristina Pinto e. O princípio de proibição de retrocesso social. Porto Alegre: Livraria do Advogado, 2010. 


\subsection{Criteria for testing new rights}

The criteria presented below were built upon the idea that openness translates the dynamicity of the rights system to evolve offering the protection claimed by human dignity and enhancing the normative strength of both the constitutional and the fundamental rights systems.

The criteria were construed as an attempt to strike an adequate balance between openness and closure of the system, revealing the conditions in which the principle of openness must be applied. As the principle of openness is no absolute, but coexists with other norms of the system, the criteria consider other normative elements that can collide with this principle. Not every advantage position or new subjective claim is able to trigger the application of the principle of openness trumping colliding norms, there must be substantial fundamentality. The fundamentality test, parametrized by the criteria, converges to the analysis of the possible normative conflicts which involve the principle of openness. This analysis aims to identify the conditions in which openness is the overweighing norm and must be applied.

To start the testing process, it is essential to draft a concept of fundamental right to which the candidate trying to enter the system must be confronted. The structure of the candidate must undergo this preliminary analysis. If the structure of the candidate copes with the constitutionally adequate definition of fundamental right, it should be analyzed to determine whether it is fundamental. Nonetheless, it is important to leave some room to the conception of fundamental right to evolve. A present acceptable concept was advanced above ${ }^{84}$.

As a threefold openness was presented, it seems important to note that the criteria to be explored do not aim with the same intensity at all forms of openness. The openness that operates through the nature of law, which has to do with legal interpretation and construing argumentation to support derivative fundamental norms, is not the first goal of the criteria. In this case, the legal argumentation is directed upon defending that a norm should be recognized as a derivative norm, i.e., as an implicit norm anchored in one or more explicit provisions which already make part of the system. This argumentation is precisely grounded on the idea that this norm is implicit, it holds formal fundamentality. Because it is implicit or derivative, it already presents a normative foundation. It is certainly important to follow an argumentation process and to highlight the substantial fundamentality, to affirm how fundamental the content defended is and how it is linked to other norms directly deduced from explicit provisions. Nonetheless, the substantial fundamentality, in this scenario, is still coupled with the formal fundamentality.

84 Specifically considered, fundamental rights are legal subjective advantage positions linked (in distinct intensity) to human dignity. Fundamental rights are positivized in a state legal order, preferably in its constitution, as legal norms with subjective and objective content, safeguarded against and through state powers. 
The main idea behind the criteria is to unveil the substantial fundamentality of rights and, departing from the assertion that this fundamentality exists, claim to treat these rights the same way as the ones which hold formal fundamentality are treated. This circumstance explains why the criteria are more suitable to test "new" rights, rights which do not profit from sufficient argumentation to be presented as already implicit in the system.

The pursuit of criteria to substantially test new candidates to enrich the fundamental rights system lays in the very foundations of fundamental rights and must be a combination of formal and substantial elements. There should be a procedure to check both source and content of rights. Nonetheless, a positive result of such a checking process must not be understood as an affirmation of the definitive validity or application of a fundamental right norm in a concrete case. Instead, the identification of substantial fundamentality leads to introducing the right in the fundamental rights system as a prima facie norm. Its application in a specific case must be verified in the very concrete case considering the other possibly applicable norms, as it happens to every norm in the system.

Concerning formal aspects, a first important observation is that openness as a principle is not itself a source of new rights, these must stem from some legitimate source of law to profit from the openness and enter the system. Rights and subjective positions may result from judicial activity which confers them broader or renewed significates through interpretation ${ }^{85}$. As for sources in strictly technical meaning, rights may be stipulated by constitutional amendment, by legislative enactment of new infraconstitutional law and by international law instruments. Openness does not create new rights. Rights established by legitimate sources may be welcomed in the system through its openness.

The sources mentioned, except from constitutional amendment and to some extent international law instruments (according to constitutional provisions), are not legitimate to "create" "new" rights granting them the status of formal constitutional norms. This is the reason these rights must undergo a test to verify their substantial fundamentality in order to claim compensatory constitutionalization. They are not born as constitutional norms; if they carry substantial fundamentality, they ought to be constitutionalized.

Even when constitutions enshrine explicit open clauses, these clauses do not provide criteria for a definitive identification of substantial fundamentality of rights.

85 PULIDO, Carlos Bernal. La fuerza vinculante de la jurisprudencia en el orden jurídico colombiano. In: CAVINO, Massimo (a cura di). Esperienze di diritto vivente: la giurisprudenza negli ordinamenti di diritto legislativo: Italia, Francia, Belgio, Germania, Spagna, Portogallo, Brasile, Argentina, Colombia. Milano: Giuffrè, 2009. v.1, p. 279-312. 
Sometimes there is some indication but, even then, there must be further theoretical and judicial elaboration. An example can illustrate what has been said. The Brazilian open clause establishes (art. 5, paragraph 2. of Brazilian Constitution): "The rights and guarantees expressed In this Constitution do not exclude others deriving from the regime and from the principles adopted by it, or from the International treaties In which the Federative Republic of Brazil is a party." When a right is established in a treaty, it can be easily identified as the source is explicitly indicated by the constitutional open clause. Still, further elaboration might be needed, because not every right in every international law provision carries the status of fundamental or human right. For the rights that derive from the regime and the principles adopted by the Brazilian constitution, it becomes evident that further inquiry and elaboration are required. The constitution does not point out by which sources these rights can be positivized (ordinary law? Judicial decisions with erga omnes effects in constitutional review - a precedent?). The substantial parameters, on their turn, are far from leading to objective or predictable answers; which fundamental content falls under deriving from the regime and from the principles adopted by the Constitution? ${ }^{86}$ This example shows that the presence of an explicit open clause does not preclude the necessity of presenting criteria to select the rights able to benefit from the openness provided by the very clause.

The same reasoning holds in the face of specific open clauses towards international law instruments. In the presence of provisions carrying rights, it might be necessary to question either they are "new" rights to the system, rights already present in the system but with different levels of protection or legal regimes, or even if they are rights with a human or fundamental right nature. International norms may also establish state obligations from which it might be possible to derive subjective advantage positions claiming to have their substantial fundamentality tested. In these cases, while the legal source question might not be an issue, the normative content remains subject to questioning ${ }^{87}$.

To what concerns the substantial criteria to find substantial fundamentality it is important to note that it did not seem adequate to seek these criteria in "natural law" because it is necessary to provide an intersubjective rationally controllable foundation for these pretense fundamental rights. The democratic state legal order should not require meta-social guarantees, and law should not be construed as image and

\footnotetext{
86 Some similar reasoning can be conducted in the face of the North American constitutional system, since the IX Amendment establishes: "The enumeration in the Constitution, of certain rights, shall not be construed to deny or disparage others retained by the people."

87 Once more the Brazilian provision may help to illustrate the situation: "International human rights treaties and conventions which are approved in each house of the national congress, in two rounds of voting, by three fifths of the votes of the respective members shall be equivalent to constitutional amendments." (Article 5 paragraph 3 of the Brazilian Constitution)
} 
likeness of a natural or metaphysical legal order based on moral pre-state suprapositive principles. As stated by Jürgen Habermas, law ought to be construed upon principles which can be rationally justified ${ }^{88}$.

Having clarified these premises about the testing criteria, it is important to bring to light the most important theoretical contributions used in their development. A significant input to the founding of new rights was sought in Ronald Dworkin's construction on principles, on the force of rights, on law's integrity, on the hermeneutic enterprise ${ }^{89}$. In addition, the consensual truth theory of Jürgen Habermas was a particularly valuable tool to reach a consensus on values through communicative rational action and discou$\mathrm{rse}^{90}$. Besides, as already signaled, the philosophical construction of Robert Alexy has a central role in the whole conception of the system of rights and its openness. This construction provides for foundations to think beyond a mere positivist approach, emphasizing the necessary connection between law and morality, without allowing morality to colonize law entirely. The latter also enabled to work within a procedural model of rules and principles, to be operated through legal argumentation ${ }^{91}$. It is evident that these theoretical foundations present, apart from some convergent points, many divergent elements, which require caution to avoid absolute incompatibilities.

Every constitutional system has its own characteristics, but it is possible to address a certain level of generalization, as pointed above. Departing from this generalization, the criteria are presented in abstract terms and should be adapted when applied to specific constitutional systems.

The criteria were construed upon the constitutional definition of fundamental rights and its core elements, seeking to provide an adequate balance between openness and closure of the fundamental rights system of the constitutional state. These are the guiding ideas to approach the criteria to test new rights:

- there is no standalone criterion;

- formal or structural criteria are not sufficient;

- the criteria presented should not be seen as absolute of immutable parameters.

\footnotetext{
88 HABERMAS, Jürgen. Direito e democracia: entre facticidade e validade. v. I. Rio de Janeiro: Tempo Brasileiro, 2012; ALEXY, Robert. The argument from injustice: a reply to legal positivism. Oxford: Oxford, 2002.

89 DWORKIN, Ronald. Taking rights seriously. Cambridge: Harvard University Press, 1978; DWORKIN, Ronald. O império do direito. São Paulo: Martins Fontes, 1999; DWORKIN, Ronald. Uma questão de princípio. São Paulo: Martins Fontes, 2000.

90 HABERMAS, Jürgen. The theory of communicative action. V. 1. Boston: Beacon. 1985; MACCARTHY, Thomas. La teoría crítica de Jürgen Habermas. Madrid: Tecnos, 1987; LAFONT, Cristina. Correctness and legitimacy in the discourse theory of law. In: KLATT, Matthias (ed.). Institutionalized reason: the jurisprudence of Robert Alexy. Oxford: Oxford, 2012, p. 291-306.

91 ALEXY, Robert. A theory of legal argumentation: the theory of rational discourse as theory of legal justification. Oxford: Oxford University Press, 2010.
} 
Departing from these guidelines, the criteria to test the substantial fundamentality of a new right are the following:

- its relevance to the norm of human dignity;

- the individual as its reference;

- its relevance to and its connection with the fundamental rights norms explicitly positivized in the constitution;

- its relevance to and its connection with the structuring elements of the fundamental rights system;

- its relevance to and its connection with the structuring principles of the constitutional state;

- its closeness to the international standards on human rights;

- its justifiability (the ability of being properly justified);

- the suitability of its source.

It seems important to explore these criteria, explaining what is understood under each of them and how they should parametrize the test of new rights.

\subsubsection{Relevance to the norm of human dignity}

The fundamental rights, which take part in the system, should serve "the direct protection and guarantee of legal goods withln the personal sphere which are Indispensable to the safeguard of every person's human dignity..." ${ }^{\prime \prime 2}$.

Hence, rights which have no formal status as constitutional norms, in order to enter the fundamental rights system through the fundamentality test, must likewise serve the protection of legal goods within the individual sphere which are indispensable to safeguarding human dignity. In the testing process, the argumentation burden ought to be adequately fulfilled showing that the new right is required by or enhances the protection and the promotion of human dignity. It should become visible that human dignity would lack important protection if the right would not be accepted in the system.

The idea is to raise human dignity as a parameter, as Jürgen Habermas points out when dealing with a constitution for Europe. Dignity is a "seismograph that Indicates what is constitutive for democratic order - which are precisely the rights that are granted to citizens of a political community and, therefore, they may consider each other as members

92 CORREIA, José Manuel Sérvulo. Direitos fundamentais: sumários. Lisboa: Associação Académica da Faculdade de Direito de Lisboa, 2002, p. 55. The piece was freely translated from the Portuguese original. 
of a voluntary association of free and equal"93. Habermas refers to a conceptual liaison between human dignity and human rights; dignity is the moral source of rights ${ }^{94}$.

Human dignity is the core element to approach a substantial concept of fundamental and human rights. The election of human dignity as the paramount parameter to fundamental rights does not seem controversial; this idea can be soundly held in the field of rights, fundamental or human ${ }^{95}$. On the opposite, taming human dignity to fit into a concept or a definition is deeply controversial, especially considering the theoretical foundations of this paper, which defend that an official definition of human dignity must be avoided ${ }^{96}$.

Reasonable moral disagreement is possible in regard to human dignity and fundamental or human rights questions. The recognition of new rights - which are situated midst such disagreements - ought to be guided by the idea of guarantying in the broadest way possible the coexistence of diverse moral conceptions. This coexistence should give room to individual autonomy to inclusively define his or her own dignity. This seems to be the best acceptable approach to human dignity in our kaleidoscopic world, especially considering the democratic element of the constitutional state and the unavoidable moral plurality of society ${ }^{97}$.

93 HABERMAS, Jürgen. The concept of human dignity and the realistic utopia of human rights. Metaphilosophy, vol. 41, no. 4, 2010, pp. 464-480. JSTOR, www.jstor.org/stable/24439631. Accessed 4 Jan. 2021, p. 464480. With a critical approach to Habermas' construction see WALKER, Neil. Habermas's European constitution: catalyst, reconstruction, refounding. (https://doi.org/10.1111/eulj.12341). Also see MCCRUDDEN, Christopher. Human dignity and judicial interpretation of human rights. European Journal of International Law. http//ssrn. com/abstract=1162024, accessed 06.01.2014; BARROSO, Luís Roberto. A dignidade da pessoa humana no direito constitucional contemporâneo: a construção de um conceito jurídico à luz da jurisprudência mundial. Belo Horizonte: Fórum, 2012.

94 HABERMAS, Jürgen. The concept of human dignity and the realistic utopia of human rights. Metaphilosophy, vol. 41, no. 4, 2010, pp. 464-480. JSTOR, www.jstor.org/stable/24439631. Accessed 4 Jan. 2021, p. 464-480.

95 ECKES, Christina. Integrated rights protection in the European and International Context: some reflections about limits and consequences. In GOVAERE, I., GARBEN, S. (Eds.). Interfaces between European and International Law (pp. 101-124). (Modern Studies in European Law; Vol. 89). Oxford: Hart Publishing, 2019. https://doi. org/10.5040/9781509923410.

96 In order to think how controversial the legally protected concept of human dignity might get it is elucidative to think about questions concerning abortion, euthanasia, drug use, genetic manipulation, new family models, to quote only a few. See HABERMAS, Jürgen. The concept of human dignity and the realistic utopia of human rights. Metaphilosophy, vol. 41, no. 4, 2010, pp. 464-480. JSTOR, www.jstor.org/stable/24439631. Accessed 4 Jan. 2021, p. 464-480; FARBER, Daniel A.. Retained by the people: the "silent" ninth amendment and the constitutional rights Americans don't know they have. New York: Basic Books, 2007, p. 115 ss; SIEGEL, Reva B.. Dignity and the politics of protection: abortion restrictions under Casey/Carhart. Faculty Scholarship Series. 2008. Paper 1134. http://digitalcommons.law.yale.edu/fss_papers/1134.

97 Justice Cançado Trindade points out to the need of crosscultural foundations to human dignity (TRINDADE, Antônio Augusto Cançado. Tratado de direito internacional dos direitos humanos. v. I. Porto Alegre: Sergio Antonio Fabris, 1999). See also PIOVESAN, Flávia. Igualdade, diferença e direitos humanos. Rio de Janeiro: Lumen Juris, 2010, p. 3-45; WESTON, Burns H.. The universality of human rights in a multicultured world: toward respectful decision-making. In WESTON, Burns H.; MARKS, Stephen P. (eds.). The future of international human rights. New York: Transnational. 1999, p. 65-99. 
One example, controversial as it may seem, illustrates the idea briefly exposed. The recognition of a right to same-sex marriage or union or its acceptance as a legal institution can be in the middle of harsh moral disagreements and may lead to disputes between diverse moral conceptions. Nonetheless, the recognition of such a legal right brings to light that the state is not embracing a particular moral conception as part of an official morality. The recognition of such a right, on the contrary, exposes the enlargement of the space of protected freedom within the boundaries of the legal system. It enables the concretization of an important aspect of human dignity by the ones who exercise this freedom and autonomously make a choice concerning their affections and unions. The right grants them adequate legal protection. At the same time, this recognition does not restrict the autonomy of the ones who are not willing to exercise such a freedom. Besides, in the democratic state, open debate about the theme remains free and possible, preserving the space for the moral disputes involved ${ }^{98}$.

This open conception of human dignity is required by the premises adopted in this paper. Notwithstanding, the conceptual openness of human dignity could represent a peril when used to test new candidates for the fundamental rights system. To diminish this peril, human dignity must be combined with other criteria and, consequently, with norms and values underlying them. Also, it is important to rely upon the contributions of Robert Alexy and Jürgen Habermas - respecting their particular conceptions - who approach human dignity through a discursive path, making its approach intersubjectively controllable. Following this path, human dignity does not claim a metaphysical morality leading to more defining and conceptualizing issues, it points to morality that can be intersubjectively exposed upon rational arguments, as already mentioned.

\subsubsection{The individual as the reference}

When seeking the substantial fundamentality of new elements to possibly enter the fundamental rights system, the image of the rights holder is central to identify the goods that could require and deserve protection. One should be able to recall the image of human being, person, individual member of a political community. A right, to be fundamental, must have this image as a reference. There must be a subjective point of normative imputation to which the right should refer.

From a complementary perspective, it must be affirmed that in the constitutional state, the individual is not isolated. The person must be regarded in its individual and unique aspects but as part of a political community. The understanding of the right

98 BARROSO, Luís Roberto. A dignidade da pessoa humana no direito constitucional contemporâneo: a construção de um conceito jurídico à luz da jurisprudência mundial. Belo Horizonte: Fórum, 2012, p. 105-106. 
holder in a dialectical relation between individual and community is required ${ }^{99}$. This implies that meta-individual needs and interests should also be considered ${ }^{100}$.

This circumstance can lead to a broadening path concerning the fundamental rights holder that results in weakening the meaning and value of fundamental rights. This devaluation is a consequence of the disconnection with the underlying norm of human dignity and the inadequacy of the legal protection means available. There are fundamental rights of collective exercise, and there are also collective rights asserted as fundamental and human rights. In these cases, however, it seems possible to still trace a strong connection between these rights and human dignity as legal protection for individuals. The question is whether this connection still holds if one grants fundamental rights to legal entities or even to depersonalized entities, such as the environment itself ${ }^{101}$.

It may be undeniable that new boundaries can and should be set for rights and all the elements concerned, including the definition of right holder. Nevertheless, if a concept or a legal instrument is artificially overstretched, it may lose its legal importance and significance. The question is not whether nature or animals, for example, deserve legal protection, but whether this protection must be offered through directly granting them fundamental rights ${ }^{102}$. Further developments towards better legal protection of the Earth and its components, towards a less anthropocentric conception should be inevitable. Notwithstanding, instead of depleting legal means of their force, it may be more efficient to think of new frameworks. Not encompassing a situation within the framework of fundamental rights does not necessarily mean or lead to diminishing its legal importance or protection. It might, on the contrary, point to the need of conceiving more suitable legal protection.

Bearing in mind the search for an adequate balance between openness and closure of the fundamental rights system, it is justifiable to require new rights to have the individual as its legal reference as explained above. This requirement guarantees the necessary connection with the underlying norm of human dignity.

\footnotetext{
99 CORREIA, José Manuel Sérvulo. Direitos fundamentais: sumários. Lisboa: Associação Académica da Faculdade de Direito de Lisboa, 2002, p. 40.

100 For an interesting approach, see HACHEM, Daniel Wunder. A dupla titularidade (individual e transindividual) dos direitos fundamentais econômicos, sociais, culturais e ambientais. Revista de Direitos Fundamentais e Democracia, v. 14, n. 14, Curitiba, p. 618-688, jul./dez. 2013.

101 For an approach to this discussion concerning the human right to a healthy environment, see BECKIUS, Louise. The human right to a healthy environment. $<\mathrm{http} / / \mathrm{www} . g \circ o g l e . c o m / u r l$ ?sa $=\mathrm{t} \& \mathrm{rct}=\mathrm{j} \& \mathrm{q}=\& \mathrm{esrc}=\mathrm{s} \&-$ source=web\&cd=15\&ved=2ahUKEwjA34zTopLnAhUS36QKHUgrABoQFjAOegQIBxAB\&url=http\%3A\%2F\%2Fwww.scriptiesonline.uba.uva.nl\%2Fdocument\%2F641667\&usg=AOvVaw0UjZFcmARXkgfH24zR_xyc> Acessed 20 january 2020.

102 See the discussion in HACHEM, Daniel Wunder; GUSSOLI, Felipe Klein. Animais são sujeitos de direito no ordenamento jurídico brasileiro? Revista Brasileira de Direito Animal, Salvador, v. 13, n. 3, p. 141-172, set./ dez. 2017.
} 


\subsubsection{Relevance to and connection with the fundamental rights norms explicitly positivi-} zed in the constitution

Relevant parameters to the compensatory constitutionalization of rights can be found in the substantial content protected by the constitution and by the fundamental rights system seen in an evolutive way.

To what regards the explicit fundamental rights norms, a core guideline is the idea of indivisibility and interpenetration of fundamental rights. All fundamental rights norms converge to delivering human dignity ${ }^{103}$ the best protection and promotion possible within the constitutional system. They are called upon in a joint enterprise, even when one fundamental right norm is more specifically adequate to a particular case. Besides, the effectiveness of one right can have strong effects on the effectiveness of other rights, what can influence positively the normative force of the rights system as a whole.

There are differences in fundamental rights regimes in many constitutions, what leads to the traditionally known dichotomy between liberty, negative or defensive rights, in the first place, and social or positive rights on the second place ${ }^{104}$. This to leave aside, at this moment, the so-called "third-generation" of rights. Many constitutions do not even positivize social rights explicitly; these rights must then be enumerated and developed through ordinary law, profiting from normative constitutional anchoring in general clauses, such as the welfare state or the principle of equality ${ }^{105}$. This cleavage

103 PÉREZ LUÑO, Antonio Enrique. Derechos humanos, estado de derecho y constitución. 9.ed. Madrid: Tecnos, 2005, p. 89.

104 Pointing to the two categories, see STERN, Klaus. Idee und Elemente eines Systems der Grundrechte. In. ISENSEE, Josef; KIRCHHOF, Paul (Hrsg.). Handbuch des Staats Rechts. V, zweite Auflage. Heidelberg: Müller, 2000, p. 70. As a very clear example of this dichotomy, see the Portuguese constitution, that treats separately what is calls "rights, freedoms and guarantees" from what are regarded as "social, cultural and economic rights". It is substantially important to notice that the following rules, on rights regime, apply only to the first category, weakening the second. The text reads: "Article 17 (Regime governing rights, freedoms and guarantees) The regime governing rights, freedoms and guarantees applies to those set out in Title II and to fundamental rights of an analogous nature. Article 18 - (Legal force): I The constitutional precepts with regard to rights, freedoms and guarantees are directly applicable and are binding on public and private entities. II The law may only restrict rights, freedoms and guarantees in cases expressly provided for in the Constitution, and such restrictions must be limited to those needed to safeguard other constitutionally protected rights and interests. III Laws that restrict rights, freedoms and guarantees must have a general and abstract nature and may not have a retroactive effect or reduce the extent or scope of the essential content of the constitutional precepts."

In the Brazilian constitutional text and practice the cleavage is not so clear as in the Portuguese context. Nonetheless, is important to notice that the norm which commands immediate application to fundamental rights norms in enshrined in Article 5, which makes part of a chapter called "individual and collective rights and duties". The social rights are enshrined in the next chapter.

105 It is interesting to notice that the German "fundamental law", in which there is an almost complete lack of rights to state concrete provisions, enshrines dignity explicitly establishing that all public authorities have the duty to respect and protect human dignity (PIEROTH, Bodo; SCHLINK, Bernhard. Grundrechte, Staatsrecht II, 11.ed., Heidelberg: C. F. Müller, 1995). Even when it is not possible to use this provision as an explicit root to rights to state concrete provisions, the idea of protection exceeds the prohibition of state interferences. See on the matter Ernst Benda, who cogitates of concrete provision duties, even related to an existential minimum 
can also be found in international law instruments, coined in the expression "generation of rights" and to be seen in some of the most influential instruments, for example, the International Covenant on Civil and Political Rights (ICCPR) and the International Covenant on Economic, Social and Cultural Rights (ICESCR) ${ }^{106}$.

Besides this cleavage, which is still the most decisive in the conception and practice of fundamental and human rights, many other classifications exist in the attempt to achieve some abstract hierarchization of rights and coin differentiated enforcement regimes $^{107}$. It seems clear that, in concrete cases, hierarchizations to solve conflicts between rights are unavoidable and result from the combined rule-principle model. This circumstance does not lead to the conclusion that fundamental and human rights should fit into rigid abstract hierarchized schemes; such a fixed conception could weaken some rights and, in consequence, all the system.

An alternative to these conceptions is built upon the deconstruction of many argumentation paths developed to rigidly hierarchize rights ${ }^{108}$ and upon the idea that fundamental and human rights are inherently intertwined, indivisible, inter dependable; they are a system built to protect human dignity in its wholeness ${ }^{109}$.

In this scenario, the explicit enumeration or recognition of specific fundamental rights is not a neutral variable. On the one hand, as already mentioned, an excessive proliferation of rights should be approached carefully. On the other hand, autonomous rights explicitly established reassure specific fundamental contents that enhance human dignity protection; they alleviate the argumentation burden to anchor these contents normatively. In addition, specific fundamental content might be called upon to support other fundamental rights and positions, reinforcing their protection and bringing indivisibility, interpenetration and interdependence into light, strengthening the

(BENDA, Ernst. Dignidad humana y derechos de la personalidad, p. 126). Also see ALEXY, Robert. Teoría de los derechos fundamentales. 2.ed. Madrid: Centro de Estudios Políticos y Constitucionales, 2007, p. 434 ss

106 EIDE, Asbjørn. Economic, social and cultural rights as human rights. In: EIDE, Asbjørn; KRAUSE, Catarina; ROSAS, Allan. Economic, social and cultural rights: a textbook. Dordrecht: Martinus Nijhoff, 1995, p. 21-40; SCHEININ, Martin. Economic, social and cultural rights as legal rights. In: EIDE, Asbjørn; KRAUSE, Catarina; ROSAS, Allan. Economic, social and cultural rights: a textbook. Dordrecht: Martinus Nijhoff, 1995, p. 41-62; LEIJTEN Ingrid. Core socio-economic rights and the European Court of Human Rights. Cambridge: Cambridge, 2018.

107 Jan Hendrik Klement wrote: "While all constitutional rights sit perfectly happily alongside each other in a basic rights order that is based solely on defensive rights, intra-constitutional rights conflicts are unavoidable in the context of a pluralist model of basic rights. ..." (KLEMENT, Jan Hendrik. Common law thinking in German jurisprudence. In: KLATT, Matthias (ed.). Institutionalized reason: the jurisprudence of Robert Alexy. Oxford: Oxford, 2012, p. 184)

108 For an interesting "deconstructing" argumentation, see SUNSTEIN, Cass; HOLMES, Stephen. The cost of rights: why liberty depends on taxes. New York: Norton, 2013. For an approach based on the indivisibility of rights, see NETTO, Luísa Cristina Pinto e. O princípio de proibição de retrocesso social. Porto Alegre: Livraria do Advogado, 2010.

109 HABERMAS, Jürgen. The concept of human dignity and the realistic utopia of human rights. Metaphilosophy, vol. 41, no. 4, 2010, pp. 464-480. JSTOR, www.jstor.org/stable/24439631. Accessed 4 Jan. 2021, p. 464-480. 
whole system. A good example is the right to science, present in international instruments but not in domestic constitutions. This right lends a good glance at the question when dealt with in combination with the right to health ${ }^{110}$; instead of a banalization of rights, the right to science can be of vital importance to guarantee health. Specific aspects that concern profiting from the benefits of scientific progress and its applications in order to protect and promote health become undeniable when the right to science is recognized.

The present criterion shows the need to compare the new right to the existing rights in the system concerning its capacity to protect and or promote human dignity. At this point, the question of whether a new candidate bears substantial fundamentality could be stated as follows: has this candidate similar capacity of protecting and or promoting human dignity as the enumerated rights? Is this candidate essential or highly needed to guarantee or enhance the effectiveness of the enumerated fundamental rights?

If the candidate offers similar protection or promotion regarding human dignity and enhances the possibilities of the rights already present in the system, it scores positively in the test, adding in the argumentative path to its compensatory constitutionalization.

Through a somewhat different perspective, it is important to notice that the indivisibility, interpenetration, and interdependence of fundamental rights does not eliminate possible conflicts which will always make part of the application of the norms of the system. That is to say that the questions here presented do not deserve a negative answer based on possible frictions involving the new right and other rights in the system. A relation of complete compatibility among rights is not expected. What is expected is common axiological root leading back to human dignity in its complexity and multifaceted nature. It is not a problem that new rights which enter the fundamental rights system collide with other specific rights; they ought to share the necessary foundations of the constitutional and of the fundamental rights system, integrating themselves in the common axiological heritage construed by the constituent power.

\subsubsection{Relevance to and connection with the structuring elements of the fundamental ri- ghts system}

New candidates to enter the fundamental rights system, as stated above, do not need to show compatibility with all encompassed rights; both rights and structuring elements can come into tension, reflecting the various and contradicting values which

110 DONDERS, Yvonne. The right to enjoy the benefits of scientific progress: in search of state obligations in relation to health. 2011. Medicine, Health Care and Philosophy, vol. 14, n. 4, 371-381. https://doi.org/10.1007/ s11019-011-9327-y. 
underlay the constitutional system and permanently seek adequation within the system. The very core of the constitutional and the rights systems carry values that often ask for compromise ${ }^{111}$; the unity of the systems is much more something to be dynamically pursued than a static given.

This is the background for testing new candidates in their relevance to and connection with the structuring elements of the fundamental rights system. The identity of the two systems involved should be preserved and promoted by the welcoming of new fundamental content, respecting the constituent choices in its evolving historicity. New candidates ought to comfortably fit in a system coined by human dignity, equality, freedom and solidarity. Their contents should serve the updating of this core elements.

\subsubsection{Relevance to and connection with the structuring principles of the constitutional state}

Following the same idea exposed above for the elements of the fundamental rights system, it is expected from candidates to enter this system that they are relevant and can connect to the structuring elements and principles of the constitutional state and its legal order. The goal of this criterion is to warrant that the welcoming of a new right will not distort the sound bonds that must tie fundamental rights and the axiological constitutional tissue. All rights, originally established in the constitutional text or resulting from compensatory constitutionalization, ought to integrate into the constituent axiological heritage ${ }^{112}$ of the democratic state.

\subsubsection{Closeness to the international standards on human rights}

The difference between fundamental and human rights has already been pointed out. Nonetheless, substantial intersections between the categories can be found. Besides, the interplay between the domestic and the international protection of rights is decisive and holds a central role when conceiving the domestic rights systems as open.

It is not possible to approach rights protection at present letting aside that states and their legal systems are embedded in a vast world of multilevel jurisdictions and mutual influences. As noticed above, an especially meaningful way in which the fundamental rights system openness operates is towards international law, as states are part of an international and global order.

111 ZAGREBELSKY, Gustavo. El derecho dúctil: ley, derechos, justicia. 8.ed. Madrid:Trotta, 2008, p. 75 ss.

112 HERRERA, Miguel Angel García. Prólogo a la segunda edición. In: BENDA, Ernst; MAIHOFER, Werner; VOGEL, Hans-Jochen; HESSE, Konrad; HEYDE, Wolfgang. Manual de derecho constitucional. 2.ed. Madrid: Marcial Pons, 2001, p. XLIII-LIX. 
On the interpretation level, the openness is seen through the mutual influence exerted on national and international legal spheres, generalizing the tendency of a broad and continuous dialogue between diverse courts. Moreover, international norms with or without jus cogens nature which impose themselves or influence domestic systems openness are visibly increasing. It is possible to find a standardization of rights legal instruments. It is also possible to affirm that human or fundamental rights are regarded as intangible by states ${ }^{113}$; they are no longer confined in the space of grants given by states to their citizens.

In the face of these phenomena, the search for substantial fundamentality gains support by anchoring new rights in international norms or standards. If the new candidate for a domestic rights system is anchored in international norms and is closely related to international provisions or standards, this contributes positively to the argumentation in favour of the candidate. This anchoring works as a vestige, a trace of its substantial fundamentality.

Certainly, this must be one criterion within multiple criteria. It is essential not to take international standards negatively, as they might, in occasions, offer a minimum level of protection. This circumstance should not conduct to denying compensatory constitutionalization to a candidate which represents a higher level of protection. The candidates must undergo the test regarding the other criteria and regarding the specificities of the domestic system in question. This aspect is also relevant because the international standards might need to be seen in the light of the historical and cultural idiosyncrasies of the concrete political community.

\subsubsection{Justifiability}

Candidates to compensatory constitutionalization must be able to be appropriately and sufficiently justified. It must be possible to develop and present rational justification in favour of the new right.

This criterion is the corollary of the other parameters, it brings the testing task to completion, disclosing the whole process. This criterion reveals how all the other criteria were dealt with and, by doing so, it renders this operation rationally controllable. In brief, justifiability unveils that, if the argumentative burden in favour of the compensatory constitutionalization of a right is adequately accomplished, the door to the rights system is open.

Justifiability as a parameter was developed counting on contributions from Jürgen Habermas' critical theory. His general reconstruction of modern legal orders and

113 PETERS, Anne. Are we moving towards constitutionalization of the world community? In: CASSESE, Antonio. Realizing utopia: the future of international law. Oxford: Oxford, 2012, p. 119-135; PETERS, Anne. Humanity as the $A$ and $\Omega$ of sovereignty. The European Journal of International Law, 2009, v. 20, n. 3, p. 513-544. 
the system of rights, using the discourse principle, is called upon to justify the compensatory constitutionalization of fundamental rights not formally enshrined in the constitution. In addition, his idea of the co-originality of autonomies is also important; private and public autonomy have equal weight and, therefore, individuals should not only be the addressees of law but also its authors ${ }^{114}$.

In Habermas' construction, it is possible to find an adequate contribution to understand modern society as post-metaphysical and, as such, a society within which a pluralism of visions must cohabitate using law as means of social coordination. In this scenario, the modern commitment to the medium of the law is central as there is no possible reach to a metaphysical response. This commitment requires "a system of statutes to ensure that every future member of the association counts as a bearer of Individual rights $^{\prime \prime 15}$.

Habermas' theory, which is not exempt to criticism, is extremely suitable for the pursuit of criteria to identify substantial fundamentality of "new" rights. Justification through rational discursive procedures becomes mandatory to the construction and operation of the openness of the rights system. The goal is to approach the rights the citizens must grant each other if they want to legitimately regulate their coexistence through positive law. Habermas seeks to give foundation to an abstract rights system recurring to the principle of discourse. Hence, his theory, even broad and general, delivers a sound departing point to the justification procedure of compensatory constitutionalization of rights.

The co-originality of subjective rights and objective law, of private and public autonomy, and an undetachable internal nexus between rights and the principle of popular sovereignty are central aspects in the reconstruction of law carried out by Habermas. He connects private and public autonomy utilizing a legal content of the political autonomy exercise: the discursive formation of opInion and will. The reconstruction of the rights systems of modern societies rests upon self-determination and self-legislation through rational discursive procedures leading to form rational will. The system of rights should legally institutionalize the conditions required by these discursive procedures. These conditions are necessary to endow the partners in law to obtain politically autonomous legislation ${ }^{116}$.

Precisely departing from the co-originality of public and private autonomy, Habermas avoids the possibility of a moral interpretation of rights; the addressees of

\footnotetext{
114 HABERMAS, Jürgen. Direito e democracia: entre facticidade e validade. v. I. Rio de Janeiro: Tempo Brasileiro, 2012.

115 HABERMAS, Jürgen. Direito e democracia: entre facticidade e validade. v. I. Rio de Janeiro: Tempo Brasileiro, 2012, p. 144-146.

116 HABERMAS, Jürgen. Direito e democracia: entre facticidade e validade. v. I. Rio de Janeiro: Tempo Brasileiro, 2012, p. 137 ss.
} 
rights are their very authors. He does not admit a moral right to liberties as an external boundary imposed on the legislator. He only acknowledges the content of rights as a formal condition to the discursive formation of opinion and will ${ }^{117}$. Equal rights and liberties must be understood through politically autonomous legislation. This leads to affirm that self-legislation does not mean a moral self-legislation of singular individuals; self-legislation is connected to the principle of discourse and to the legal form. The result is the principle of democracy, which is the core of the rights system ${ }^{118}$.

This construction and its elements can suitably engage in the conception of law presenting a claim to correctness, as drafted above. The need for justification found in Habermas, which makes the individual at the same time addressee and author of the legal order (especially regarding the system of rights), supports the claim to correctness. This claim is not externally or heteronomously imposed by a moral order superior to law. Claim to correctness - substantial requirements to a "correct" law - must be understood as a result construed through rational discursive procedures within historical-political contexts. Politically autonomous legislation is made in concrete settings which enable to identify substantial requirements - also through rational, discursive procedures - needed by law and the rights system to be legitimate.

Habermas, on his general level of cogitation, does not indicate substantial boundaries for this self-legislation. On the level before the concrete organization of the state, he indicates indispensable rights required by a "legitimate" law, affirming that they ought to be structured by the legislator ${ }^{119}$. In other words, he reaffirms the co-originality of the public and private autonomy.

Departing from the liaison between people sovereignty and fundamental rights, Habermas proceeds to the reconstruction of the rights system in an "explanatory or comprehension theoretical exercise". The construction of a concrete rights system by the constituent power should presuppose the principle of discourse and the legal form; the liberty rights are the necessary enabling conditions to establish the "legal code" once they are the means to the exercise of political autonomy. Habermas does not conceive the rights system as originated in natural law or in a moral order superior to law that should only be translated into law by the constituent power. As mentioned, he avoids this "duplication" of law; law is not a reproduction of morality ${ }^{120}$.

\footnotetext{
117 HABERMAS, Jürgen. Direito e democracia: entre facticidade e validade. v. I. Rio de Janeiro: Tempo Brasileiro, 2012, p. 164.

118 HABERMAS, Jürgen. Direito e democracia: entre facticidade e validade. v. I. Rio de Janeiro: Tempo Brasileiro, 2012, p. 162-163.

119 HABERMAS, Jürgen. Direito e democracia: entre facticidade e validade. v. I. Rio de Janeiro: Tempo Brasileiro, 2012, p. 164-166.

120 HABERMAS, Jürgen. Direito e democracia: entre facticidade e validade. v. I. Rio de Janeiro: Tempo Brasileiro, 2012, p. 166.
} 
In the context of legal orders not grounded in metaphysical or religious foundations, practical guidance can only be approached rationally through argumentation. The understanding of the connection between law and morality is of paramount importance. Morality is not to be duplicated into law. Therefore, it is necessary to use rational argumentation to agree on the validity of norms to guide actions.

This conception warrants the centrality of the human person which is indispensable to the construction presented in this paper. The individual is not only the addressee of the legal order, but the author of this order through political autonomy. The decisions about the rights systems in modern democratic societies can only be taken employing this autonomy, using rational discursive procedures. It is continuously necessary to reach renewed moral consensus, procedurally forged, to determine which rights are indispensable to the participation in the democratic discourse ${ }^{121}$.

Without adhering completely to Habermas' critical theory, what would require developments that go far beyond the goal of this paper, it is crucial to retain that Habermas' conception of the system of rights is situated within a discursive comprehension of law. This reveals the umbilical connection between democracy and rights. In his theory, the construction of law results from the exercise of political autonomy by citizens. Translating these ideas into the theme of the paper, it is possible to assert that the decision of which rights deserve compensatory constitutionalization is central to structuring the state and the political community ${ }^{122}$.

The rights system is for Habermas the heart of the legitimate law; without such a system, there is no legitimacy in law. This is a bridge to bind Habermas' and Alexy's theories in delivering the adequate theoretical foundation to the openness of the fundamental rights system and the criteria for the compensatory constitutionalization. The idea of legitimate law approaches the conception of law holding a claim to correctness; both do not strive for a transcendental morality but ask for a rationally discursively construed morality.

The necessity of taking decisions through rational discursive processes makes more sense when linked to the need to justify these decisions. This emphasizes that legal reasoning and legal argumentation ought to be carried within rational criteria. Law holds a claim to correctness, but not only law as a system. This claim also spreads itself to the norms and decisions taken within the system. Justifiability comes into play.

\footnotetext{
121 BUSTAMANTE, Thomas da Rosa de. Teoria do precedente judicial: a justificação e a aplicação de regras jurisprudenciais. São Paulo: Noeses, 2012, p. 158

122 Matthias Klatt points out that, according to Robert Alexy, the role of fundamental rights in legal system is characterized by the fact that they represent highly relevant issues for individuals and society (KLATT, Matthias. Robert Alexy's philosophy of law as system. In: KLATT, Matthias (ed.). Institutionalized reason: the jurisprudence of Robert Alexy. Oxford: Oxford, 2012, p. 7). See ALEXY, Robert. Teoría de los derechos fundamentales. 2.ed. Madrid: Centro de Estudios Políticos y Constitucionales, 2007, p. 462-463.
} 
The claim to correctness, as here understood, leads inevitably to a claim to justification; correctness implies justifiability ${ }^{123}$.

According to Robert Alexy, legal reasoning ought to enable the logical inferences which provide internal justification, and which reveal the premises that require external justification ${ }^{124}$. His legal argumentation theory must be combined with his non-positivist law's conception; it is not possible to fulfil the claim to justifiability recurring exclusively to normative provisions and authoritative arguments. At this point, attention is drawn upon the necessary connection between law and morality. If law, with its open texture, leads to more than one interpretation possible, but if there is a moral argument that favours one interpretation, this one ought to be chosen, fulfilling the claim to correctness. This choice should be justifiable through legal rational argumentation, fulfilling, by its turn, the claim to justifiability ${ }^{125}$.

A significant criticism can be delivered on this understanding; an undesirable and unacceptable identification between law and morality ${ }^{126}$. This criticism can be dealt with using Robert Alexy's comprehension of fundamental rights related to his non-positivistic law's conception. It is possible to assert the existence per se of fundamental rights conceiving them as elementary moral postulates and explaining the connection between law and morality as a classificatory relation in which fundamental rights are central. On the one hand, fundamental rights imply the use of moral considerations to justify themselves. On the other hand, they avoid these ethical considerations from colonizing law completely. Fundamental rights deliver an important contribution to balancing the tension caused by the necessary connection between law and morality ${ }^{127}$.

\footnotetext{
123 KLATT, Matthias. Robert Alexy's philosophy of law as system. In: KLATT, Matthias (ed.). Institutionalized reason: the jurisprudence of Robert Alexy. Oxford: Oxford, 2012, p. 15-16. See also ALEXY, Robert. The argument from injustice: a reply to legal positivism. Oxford: Oxford, 2002, p. 76 ss.

124 KLATT, Matthias. Robert Alexy's philosophy of law as system. In: KLATT, Matthias (ed.). Institutionalized reason: the jurisprudence of Robert Alexy. Oxford: Oxford, 2012, p. 3-4.

125 KLATT, Matthias. Robert Alexy's philosophy of law as system. In: KLATT, Matthias (ed.). Institutionalized reason: the jurisprudence of Robert Alexy. Oxford: Oxford, 2012, p. 15 ss.

126 HABERMAS, Jürgen. Direito e democracia: entre facticidade e validade. v. I. Rio de Janeiro: Tempo Brasileiro, 2012, p. 139 ss.

127 KLATT, Matthias. Robert Alexy's philosophy of law as system. In: KLATT, Matthias (ed.). Institutionalized reason: the jurisprudence of Robert Alexy. Oxford: Oxford, 2012, p. 15 ss. Robert Alexy distinguishes between rules and principles and asserts that this distinction and the principial comprehension of fundamental rights leads to the necessary connection between law and morality. This happens by means of three theses: the thesis of incorporation (all legal system has principles), the morality thesis (the incorporation of principles in the system leads to the necessary connection between law and critical morality); the correctness thesis (there is a necessary connection between law and morality). This relation is linked to the dual nature of law - real and ideal - asserted by Alexy, having consequences on his concept of law and on legal argumentation. Matthias Klatt writes: "legal argumentation implies moral reasoning" (KLATT, Matthias. Robert Alexy's philosophy of law as system. In: KLATT, Matthias (ed.). Institutionalized reason: the jurisprudence of Robert Alexy. Oxford: Oxford, 2012, p. 22). See also KLATT, Matthias; MEISTER, Moritz. The constitutional structure of proportionality. Oxford: Oxford, 2012.184 p.
} 
Robert Alexy's conception of fundamental rights as elementary moral postulates can be related to the habermasian idea that there are moral requirements imposed by the principle of discourse. This is especially relevant regarding fundamental rights without which the legitimate production of legal norms is not viable. These requirements amount over historical time and construct themselves as indispensable; these requirements become incorporated in humanity legal and moral heritage. It is not necessary to recall realist thesis over a substantial moral content to law; it is possible to try a rational justification to this content considering it as "deflnitive moral learnlng propitiated by modernity"128. This comprehension on Habermas' theory can be found in his latest works. It provides for a foundation for fundamental rights linked with the complementarity between by law and morality construed through this discursive "moral learning"129.

In this scenario, the justification of fundamental rights requires a morality which is rationally construed and whose grounding arguments can be exposed through argumentation ${ }^{130}$. This is certainly an aspect that enables congregating elements from both Alexy's and Habermas' theories.

A pivotal element to Robert Alexy's construction viewed systematically is law's discursive rationality ${ }^{131}$. His claim to correctness and the relation between law and morality refers to a broad notion of justice, gathering ethic, pragmatic and moral aspects of correctness $^{132}$. In Alexy's theory, the connection between fundamental rights and legal argumentation is close, deep and complex. Their normative structure as legal principles implies the institutional need for balancing and, therefore, of recurring to the theory of legal argumentation. Balancing must be done in a rational and controllable way. The relation between law and morality presents an institutional dimension, which means rights institutionalization in a legal system with constitutional review. The legal system

128 HABERMAS, Jürgen. Direito e democracia: entre facticidade e validade. v. I. Rio de Janeiro: Tempo Brasileiro, 2012, p. 166; BUSTAMANTE, Thomas da Rosa de. Teoria do precedente judicial: a justificação e a aplicação de regras jurisprudenciais. São Paulo: Noeses, 2012, p. 157-158.

129 HABERMAS, Jürgen. The concept of human dignity and the realistic utopia of human rights. Metaphilosophy, vol. 41, no. 4, 2010, pp. 464-480. JSTOR, www.jstor.org/stable/24439631. Accessed 4 Jan. 2021, p. 464-480. 130 KLATT, Matthias. Robert Alexy's philosophy of law as system. In: KLATT, Matthias (ed.). Institutionalized reason: the jurisprudence of Robert Alexy. Oxford: Oxford, 2012, p. 22.

131 KLATT, Matthias. Robert Alexy's philosophy of law as system. In: KLATT, Matthias (ed.). Institutionalized reason: the jurisprudence of Robert Alexy. Oxford: Oxford, 2012, p. 22.

132 This interpretation can be found in Maeve Cooke: "It is an open question what justice in the broader sense requires. This follows from the view of concepts, together with the discourse-theoretical approach to validity, that I have attributed to Alexy. I have suggested that these lead to a conception of legal philosophy in which the claims to correctness raised for concepts of law are subject to critical evaluation in open-ended processes of argumentation. This holds for the concept of justice as much as for the concept of law." (COOKE, Maeve. The dual character of concepts and the discourse theory of law. In: KLATT, Matthias (ed.). Institutionalized reason: the jurisprudence of Robert Alexy. Oxford: Oxford, 2012, p. 283) 
must incorporate equality and liberty reclaimed by legal discourse; it must constitute a discursive democracy ${ }^{133}$.

From another perspective, law's open texture and the limits of discursive rationality bring to light the importance of law's real dimension, its positivity. Because discourse norms do not lead to one correct answer or interpretation but can deliver different solutions revealing reasonable moral disagreements, positive legal norms are necessary to provide a definitive solution. Robert Alexy names this as Institutionalizlng reason, which culminates in the political form of liberal democracy, of discursive constitutionalism. This political form guarantees, at the same time, democracy and fundamental rights ${ }^{134}$. Legal discourse requires that democracy and fundamental rights are incorporated in the legal system. Democracy because dialogue only can be realized in deliberative democracy; fundamental rights because discourse is based on liberty and equality ${ }^{135}$.

Without disregarding relevant points of contrast and friction between Jürgen Habermas' and Robert Alexy's theories, the reasoning developed above made it possible to find approaching elements between them. These elements enable to work with both constructions as substantial ground for the ideas and conclusions developed in this paper. The first author contrasts facticity with validity, the second affirms the dual nature of law - one real dimension and one ideal or critical. The first presents a system of rights without which a legitimate law in unviable; the second understands fundamental rights are indispensable to law's claim to correctness. The first asserts that the rights system ought to enable the legal institutionalization of the conditions required by the discursive procedures ${ }^{136}$; the second affirms that the legal system, because of discursive claims, requires fundamental moral values in the form of fundamental rights ${ }^{137}$.

133 KLATT, Matthias. Robert Alexy's philosophy of law as system. In: KLATT, Matthias (ed.). Institutionalized reason: the jurisprudence of Robert Alexy. Oxford: Oxford, 2012, p. 19 ss. On page 23 this piece on the connection between fundamental rights and discourse can be found: "... In the philosophical dimension, basic rights are justified with the help of the discourse thesis. In the political dimension, discourse theory specifies a particular political form for the institutionalization of basic rights. In the juridical dimension, the theory of balancing as a part of the principles thesis contributes to the theory of legal argumentation as a whole."

134 ALEXY, Robert. Teoria do discurso e sistema jurídico. In: ALEXY, Robert. Teoria discursiva do Direito. Rio de Janeiro: Forense Universitária, 2014, p. 87-89; KLATT, Matthias. Robert Alexy's philosophy of law as system. In: KLATT, Matthias (ed.). Institutionalized reason: the jurisprudence of Robert Alexy. Oxford: Oxford, 2012, p. 22-25.

135 KLATT, Matthias. Robert Alexy's philosophy of law as system. In: KLATT, Matthias (ed.). Institutionalized reason: the jurisprudence of Robert Alexy. Oxford: Oxford, 2012, p. 22-25

136 LAFONT, Cristina. Correctness and legitimacy in the discourse theory of law. In: KLATT, Matthias (ed.). Institutionalized reason: the jurisprudence of Robert Alexy. Oxford: Oxford, 2012, p. 291-306.

137 HABERMAS, Jürgen. Direito e democracia: entre facticidade e validade. v. I. Rio de Janeiro: Tempo Brasileiro, 2012, p. 137 ss; KLATT, Matthias. Robert Alexy's philosophy of law as system. In: KLATT, Matthias (ed.). Institutionalized reason: the jurisprudence of Robert Alexy. Oxford: Oxford, 2012, p. 24; ALEXY, Robert. Comments and responses. In: KLATT, Matthias (ed.). Institutionalized reason: the jurisprudence of Robert Alexy. Oxford: Oxford, 2012, p. 329-330/353, footnote 121. Robert Alexy explains that, in many cases, the reasonable 
Maybe the link to connect the two theoretical constructions in this present paper is to be found in the goals of law's discursive theories: "the defence of moral cognitivism, of norms' claim to correctness, of the rational justifiability of norms, of the importance of political deliberation for democratic legitimacy"138. Briefly, what is at stake is exposing the relationship between discursive agreements and the validity of legal norms.

This discursive conception of law and its application in the justification of rights, identifying their substantial fundamentality, suit the comprehension of the legal system and of an open fundamental rights system that underly the whole conception exposed in this paper. The aim to be achieved through compensatory constitutionalization, either on the interpretative level or on the normative creation level, is not to discover rights in a transcendental moral order and affirm them as legally binding. The aim is to justify the recognition of elements that ought to take part in the rights system because of their relevance for human dignity within a democratic state. This justification is construed through rational discursive procedures that sustain the decision of affirming the substantial fundamentality of new rights. Certainly, the procedures may reckon on moral considerations which should undergo rational discursive requirements.

The rational and the discursive aspects involved in the justifiability of the candidates to enter the fundamental rights system are essential to the ideas of legitimate law and law's claim to correctness. Only through discursive processes that are conducted by reason can the rationality of the identification of substantial fundamentality be affirmed, avoiding considerations based on natural law or on a transcendent moral order. Besides, justifiability links itself to the possibility of rational discursive procedures; the substantial fundamentality of the candidates is grounded in their necessity and relevance to the viability of these very discursive procedures. Candidates to enter the system should show their importance for guaranteeing the rational discursive procedures, their importance to discursive constitutionalism, to both public and private autonomies.

If the task is fulfilled, i.e., if the argumentative burden is carried out in the face of the criteria presented above in favour of a candidate to enter the fundamental rights system, its substantial fundamentality should be recognized. Undoubtedly, it is a complex and multifaceted argumentative pathway; it is not enough to demonstrate

disagreement cannot be solved because discourse is not a procedure which is able to always conduct to a one right answer. Even though, there are cases in which it is possible to solve the disagreement by means of what is discursively necessary. This is the case for fundamental rights and democracy.

For a comparison between the ideas of correctness and legitimacy in the discursive theories of Robert Alexy and Jürgen Habermas, see, LAFONT, Cristina. Correctness and legitimacy in the discourse theory of law. In: KLATT, Matthias (ed.). Institutionalized reason: the jurisprudence of Robert Alexy. Oxford: Oxford, 2012, p. 291-306.

138 LAFONT, Cristina. Correctness and legitimacy in the discourse theory of law. In: KLATT, Matthias (ed.). Institutionalized reason: the jurisprudence of Robert Alexy. Oxford: Oxford, 2012, p. 291. 
the existence and validity of a legal norm entailing a right. This path requires the demonstration that a legal and valid legal norm conveys a right claimed by the central issues concerning the political community and the state, a right without which human dignity protection cannot be guaranteed and, consequently, without which there is no legitimate law, no law that fulfils the claim to correctness.

The task involves moral considerations and cannot deliver results exempt from controversy. Absolute objectivity is not attainable, a right answer to all the hypotheses is not feasible. If complete objectivity is not achievable, it does not follow that the process is irrational. The goal of the process of testing new candidates and trying to identify their substantial fundamentality, with the help of legal argumentation, is to expose this test submitting it to an argumentative path where justification and intersubjectivity control are required ${ }^{139}$.

Finally, justifiability also concerns the necessity of indicating a valid legal provision that functions as the legal source of the candidate to enter the rights system. If the candidate is a derivative (implicit) norm, in its justification process the explicit provisions to which it is anchored should be presented. It is possible in this case to reckon on interpretation assertions made before; the operation to derivate a norm from explicit provisions depends on legal argumentation ${ }^{140}$. In other cases, the legal source of the candidate will be an ordinary law provision or an international law instrument provision, as hereafter explained.

\subsubsection{Suitability of the source}

As a last aspect, in the testing process of new rights it is important to answer the question about which normative source is suitable to establish a right that could be considered fundamental and deserve compensatory constitutionalization.

All the exposition in this paper assumes a general character as pointed out in the beginning. It is hence important to notice that, when considering a specific constitutional system, attention must be paid to the concrete norms of the system, especially regarding the accepted sources of law.

Moral argumentation can undoubtedly play a role in asserting the need to constitutionalize a right recognizing its substantial fundamentality, but this is not enough to include the right in the legal system as a valid norm. Even when the incompleteness of the formal constitution is recognized and when the need to compensatory

\footnotetext{
139 Carlos Bernal Pulido asserts that absolute objectivity is an utopia, not attainable in any normative domain (PULIDO, Carlos Bernal. Estudio introductorio. In: ALEXY, Robert. Teoría de los derechos fundamentales. Madrid: Centro de Estudios Políticos y Constitucionales, 2007, p. XLV). See also ALEXY, Robert. Teoría de los derechos fundamentales. 2.ed. Madrid: Centro de Estudios Políticos y Constitucionales, 2007, p. 486 ss.

140 ALEXY, Robert. Teoría de los derechos fundamentales. 2.ed. Madrid: Centro de Estudios Políticos y Constitucionales, 2007, p. 53-55.
} 
constitutionalization of rights required by the claim to correctness is advocated, it is inevitable to respect a formal criterion to identify the acceptable legal sources. Otherwise, law as a system would collapse.

This circumstance is even more relevant since Robert Alexy's and Jürgen Habermas' theories were the basis of the argumentative pathway structured to test new candidates to the rights system. Their contribution to the theoretical level must find ground in the real dimension of law, within positivized valid law. This formal requirement can be regarded as a requirement of law as a positive construction. Besides, it is required by the necessary imbrication of rights and democracy, the co-originality of private and public autonomy. There must be a sufficiently institutionalized form of production of a provision to render it legally binding, making it a legal source able to convey a fundamental right.

The requirement that a formal criterion is fulfilled does not make the compensatory constitutionalization of rights impossible. As assumed that rights and democracy must coexist in the constitutional state, the fulfilment of a formal criterion is essential. If it is viable to come discursively to an agreement on the need of a right to the protection of human dignity based on substantial reasons rationally explainable, it should also be possible to convey it through a suitable legal provision.

\section{CLOSING REMARKS}

History and its evolving circumstances enable human dignity to unfold. At the same time, these circumstances present human dignity with renewed threats, which require that the set of rights positivized in states constitutions and in international law also evolve in order to effectively warrant human dignity. Hence, these systems of rights must be conceived as open systems, capable of accepting and accommodating new interpretations and new rights.

The openness of the rights system was here addressed as a broader phenomenon which goes beyond the existence of explicit open clauses for new rights. Openness can operate on the levels of interpretation and of normative creation through different paths - originated from law's nature, derived from an implicit principle, and imposed by the interaction between national and international law - and counting on various ways of realization - legislative concretization of fundamental rights, judicial application of law, explicit open clauses, constitutional amendment, and impositions from international law. Openness assures the updating capacity of the rights system in favour of human dignity.

Human and fundamental rights are powerful legal means to protect and promote human dignity. Nonetheless, it does not simply follow that the more rights, the better human dignity will be guaranteed. On the one hand, the recognition of implicit 
and new rights appears unavoidable and desirable. On the other hand, it can lead to rights proliferation with deleterious effects, among others, on the domestic separation of powers, on the capacity of states to guarantee rights, on the normative force of rights. An artificial proliferation of rights can weaken rights' legal and political worth; when everything is fundamental, nothing is really fundamental.

The possible aspects of an alleged rights overreach are being called into discussion domestically and internationally, midst globalization, the growing populist belt worldwide, migration and environmental challenges.

It is crucial to bear in mind the importance of rights beyond aspirational postulates, as effective legal means to protect human dignity, which imply feasible obligations. In this scenario, it is urgent to offer theoretical foundations to the openness of the fundamental rights system. The presentation of these theoretical foundations in this paper intended to preserve the core values and elements of the system, and to prevent the denaturation of the concept of rights. The set of rights granted the status of fundamental or human rights cannot expand limitless; openness must be combined with some degree of closure.

The search for balance between openness and closure was addressed in this paper by presenting and exploring a set of criteria to identify the substantial fundamentality of rights. These criteria should guide every update of the system by revealing the presence of substantial fundamentality in rights not formally enshrined in the constitutional text. The criteria function as parameters to the compensatory constitutionalization of rights; the criteria should be applied to candidates entering the fundamental rights system either by the door of interpretation - implicit rights - or by the door of normative creation - new rights. This testing path was structured as an attempt to scrutinize "new" rights and verify if they should be granted the status of fundamental right.

Eventually, the paper exposed the reasoning needed in testing implicit and new rights. This complex testing task can only be fulfilled by leaning on legal argumentation and interpretation theories; it is a discursive process that must be conducted by rational and intersubjectively controllable argumentation.

The construction of criteria to scrutinize new rights engages in the effort to readdress the rights discourse and protect rights against artificial proliferation. As a following research step, it seems necessary to put these very criteria to test in order to verify their usefulness. A complementary development, hence, should lead to applying the criteria to alleged new rights, such as a right to science ${ }^{141}$ or a right to internet

141 The affirmation of the right to science as an autonomous fundamental right which merits compensatory constitutionalization was the central focus of my postdoc research period at Amsterdam University (ACIL-UVA). A paper on the subject is being prepared. 
$\operatorname{access}^{142}$, among many others. This further elaboration, besides a more concrete aspect, should not disregard the need to delve into the increasing challenges posed to democracy and their possible consequences on rights.

At the end is seems imperative to conclude that the attempt to offer mechanisms to maintain the rights system open as well as to prevent the artificial proliferation of rights is not able to deliver an absolute answer, it lays in a discursive process that reinforces the mutual relation between rights and democracy.

\section{REFERENCES}

ALEXANDRINO, José de Melo. A estruturação do sistema de direitos, liberdades e garantias na constituição portuguesa: a construção dogmática. v. Il. Coimbra: Almedina, 2006.

ALEXY, Robert. A theory of constitutional rights. Oxford: Oxford University Press, 2010

ALEXY, Robert. A theory of legal argumentation: the theory of rational discourse as theory of legal justification. Oxford: Oxford University Press, 2010.

ALEXY, Robert. Basic rights and democracy in Jürgen Habermas's procedural paradigm of the law. Ratio juris, v. 7, n. 2, jul., 1994, p. 227-238.

ALEXY, Robert. Comments and responses. In: KLATT, Matthias (ed.). Institutionalized reason: the jurisprudence of Robert Alexy. Oxford: Oxford, 2012, p. 319-356.

ALEXY, Robert. Constitutional rights, balancing and rationality. Ratio juris, v. 16, n. 2, jun., 2003, p. 131-140.

ALEXY, Robert. Grundrecht als subjektive Rechte und als Objektive Normen. Der Staat, 29. Band, Heft 1, 1990, p. 49-68.

ALEXY, Robert. La institucionalización de los derechos humanos en el Estado constitucional democrático. Derechos y libertades: Revista del Instituto Bartolomé de las Casas. Madrid, ano V, n. 8, ene./jun., 2000, p. 21-41.

ALEXY, Robert. On the thesis of a necessary conexion between law and morality: Bulygin's critique. Ratio juris, v. 13, n. 2, jun., 2000, p.138-147.

ALEXY, Robert. Rechtssystem und praktische Vernunft. Rechtstheorie, 18. Band, 1987, Heft 4, p. 405-419.

142 For an interesting approach referring a right to internet access within a broad discussion, see RANCHORDAS, Sofia. The Digitalization of Government and Digital Exclusion: Setting the Scene (April 29, 2020). University of Groningen Faculty of Law Research Paper, forthcoming In Ferreira Mendes, G. \& Blanco de Morais, C. (eds.). Direito Publico e Internet: Democracia, Redes Sociais e Regulação do Ciberespaço FGV Publicacoes/IDP/ Univ. Lisboa, (Public Governance 4.0, 2020)., Available at SSRN: https://ssrn.com/abstract=3663051 or http:// dx.doi.org/10.2139/ssrn.3663051. 
ALEXY, Robert. Teoría de los derechos fundamentales. 2.ed. [Traducción de Carlos Bernal Pulido] Madrid: Centro de Estudios Políticos y Constitucionales, 2007.

ALEXY, Robert. Teoria do discurso e sistema jurídico. In: ALEXY, Robert. Teoria discursiva do Direito. Rio de Janeiro: Forense Universitária, 2014, p. 75-89.

ALEXY, Robert. The argument from injustice: a reply to legal positivism. [Translated by Bonnie Litchewski Paulson and Stanley L. Paulson] Oxford: Oxford, 2002.

ALEXY, Robert. The nature of legal philosophy. Ratio juris, v. 17, n. 2, jun., 2004, p. 156-167.

ALLAN, T. R. S. Constitutional rights and the rule of law. In: KLATT, Matthias (ed.). Institutionalized reason: the jurisprudence of Robert Alexy. Oxford: Oxford, 2012, p. 132-151.

ANDRADE NETO, João. Borrowing justification for proportionality: on the influence of the principles theory in Brazil. Springer, 2018.

BALDE, Aua. O direito ao desenvolvimento como um direito fundamental. In: African human rights yearbook. V 3. Pretoria: Pretoria University Press, 2019, p. 49-71.

BAPTISTA, Eduardo Correia. Ius cogens em direito internacional. Lisboa: Lex, 1997.

BARNETT, Randy E. Reconceiving the ninth amendment. 74 Cornell Law Review, 1, 1988-1989, p. 1-42.

BARNETT, Randy E.Who's afraid of unenumerated rights. University of Pennsylvania Journal of Constitutional Law, 1, 2006-2007, p. 1-22.

BARROSO, Luís Roberto. A dignidade da pessoa humana no direito constitucional contemporâneo: a construção de um conceito jurídico à luz da jurisprudência mundial. Belo Horizonte: Fórum, 2012.

BECKIUS, Louise. The human right to a healthy environment. <http://www.google.com/ url? sa $=t \& r c t=j \& q=\& e s r c=s \&$ source $=$ web\&cd=15\&ved=2ahUKEwjA34zTopLnAhUS36QKHUgrABoQFjAOegQIBxAB\&url=http\%3A\%2F\%2Fwww.scriptiesonline.uba.uva.nl\%2Fdocument\%2F641667\&usg=AOvVaw0UjZFcmARXkgfH24zR_xyc> Acessed 20 january 2020.

BENDA, Ernst. El Estado social de derecho. In: BENDA, Ernst; MAIHOFER, Werner; VOGEL, Hans-Jochen; HESSE, Konrad; HEYDE, Wolfgang. Manual de derecho constitucional. 2.ed. Madrid: Marcial Pons, 2001, p. 487-559.

BIANCHI, Andrea. Human rights and the magic of jus cogens. The European Journal of International Law, Vol. 19 no. 3 ๑ EJIL 2008.

BIX, Brian. Law, Language, and Legal Determinacy. Published to Oxford Scholarship Online: March 2012. DOI: 10.1093/acprof:oso/9780198260509.001.0001.

BIX, Brian. H. L. A. Hart and the "Open Texture" of Language. Springer. Law and Philosophy, Vol. 10, No. 1 (Feb., 1991). 
BÖCKENFÖRDE, Ernest-Wolfgang. Estudios sobre el Estado de Derecho y la democracia. Madrid: Trotta, 2000.

BÖCKENFÖRDE, Ernst-Wolfgang. Grundrechte als Grundsatznormen. Der Staat (Zeitschrift für Staatslehre, öffentliches Recht und Verfassungsgeschicht). 29. Band. Berlin, Duncker und Humblot, 1990, p. 1-31.

BOROWSKI, Martin. La restricción de los derechos fundamentales. Revista Española de Derecho Constitucional, Madrid, ano 20, n. 59, mayo-agosto, 2000, p. 29-56.

BREWER-CARÍAS, Allan. Constitutional protection of human rights in Latin America. Cambridge, 2009.

BRÖLMANN, Catherine, BINDER, Christina. The law of treaties before domestic courts and human rights bodies. Amsterdam Law School Legal Studies Research Paper No. 2017-41 Amsterdam Center for International Law No. 2017-27.

BULYGIN, Eugenio. Alexy's thesis of the necessary connection between law and morality. Ratio juris, v. 13, n. 2, jun., 2000, p. 133-137.

BULYGIN, Eugenio; MENDONÇA, Daniel. Normas y sistemas normativos. Madrid: Marcial Pons, 2005.

BURGERS, Laura; STAAL, Tim Climate action as positive human rights obligation: the appeals judgment in Urgenda $v$ the Netherlands. In WESSEL, Ramses A; WERNER, Wouter; BOUTIN, Bérénice (Eds.) Netherlands Yearbook of International Law 2018, T.M.C. Asser Press, forthcoming in spring 2019. Centre for the Study of European Contract Law Working Paper Series No. 2019-01.

BUSTAMANTE, Thomas da Rosa de. Teoria do precedente judicial: a justificação e a aplicação de regras jurisprudenciais. São Paulo: Noeses, 2012.

CANARIS, Claus-Wilhelm. Pensamento sistemático e conceito de sistema na ciência do direito. 2.ed. Lisboa: Fundação Calouste Gulbenkian, 1996.

CANOTILHO, J. J. Gomes. Direito constitucional e teoria da constituição. 7.ed. Coimbra: Almedina, 2003.

CASSESE, Sabino. La globalización jurídica. Madrid: Marcial Pons, 2006.

COOKE, Maeve. The dual character of concepts and the discourse theory of law. In: KLATT, Matthias (ed.). Institutionalized reason: the jurisprudence of Robert Alexy. Oxford: Oxford, 2012, p. 275-290.

CORREIA, José Manuel Sérvulo. Direitos fundamentais: sumários. Lisboa: Associação Académica da Faculdade de Direito de Lisboa, 2002.

CRIDDLE, Evan; FOX-DECENT, Evan. Fiduciaries of humanity: how international law constitutes authority. Oxford scholarship online. 2016 (DOI:10.1093/acprof:oso/9780199397921.001.0001). 
DE WET, Erika. The emergence of international and regional value systems as a manifestation of the emerging international constitutional order. Leiden Journal of International Law, 2006, n. 19, p. 611-632.

DE WET, Erika. The emerging international constitutional order: the implications of hierarchy in international law for the coherence and legitimacy of international decision-making. PER/PLJ, 2007 , v. 10 , n. 2, p. 21-46.

DE WET, Erika. The international constitutional order. International and Comparative Law Quarterly, 2006, jan., v. 55, p. 51-76.

DE WET, Erika. The prohibition of torture as an international norm of jus cogens and its implications for national and costumary law. European Journal of International Law, 2004, v. 15, n. 1, p. 97-121.

DOBNER, Petra. More law, less democracy?: democracy and transnational constitutionalism. In: DOBNER, Petra; LOUGHLIN, Martin. The twilight of constitutionalism? Oxford: Oxford, 2012, p. $141-161$.

DONDERS, Yvonne. Cultural Rights in International Human Rights Law: From Controversy to Celebration (June 26, 2020). published in: Japanese Yearbook of International Law ("Cultural Rights in International Human Rights Law: From Controversy to Celebration", Japanese Yearbook of International Law, Vol. 62 (2019) International Law Association of Japan (February 2020), pp. 61-84.), Amsterdam Law School Research Paper No. 2020-35, Amsterdam Center for International Law No. 2020-13, Available at SSRN: https://ssrn.com/abstract=3635993.

DONDERS, Yvonne. The right to enjoy the benefits of scientific progress: in search of state obligations in relation to health. 2011. Medicine, Health Care and Philosophy, vol. 14, n. 4, 371-381. https://doi.org/10.1007/s11019-011-9327-y.

DONDERS, Yvonne. Towards a right to cultural identity?. Cambridge: Intersentia, 2002.

DONDERS, Yvonne; LAAKSONEN, Annamari. Finding Ways to Measure the Cultural Dimension of Human Rights and Development (November 9, 2009). (SSRN: https://ssrn.com/abstract=1657837 or http://dx.doi.org/10.2139/ssrn.1657837)

DWORKIN, Ronald. O império do direito. São Paulo: Martins Fontes, 1999.

DWORKIN, Ronald. Taking rights seriously. Cambridge: Harvard University Press, 1978.

DWORKIN, Ronald. Uma questão de princípio. São Paulo: Martins Fontes, 2000.

DWORKIN, Ronald. Unenumerated Rights: whether and how Roe should be overruled. The University of Chicago Law Review, 59.1992, p. 381-432.

ECKES, Christina. Integrated rights protection in the European and International Context: some reflections about limits and consequences. In GOVAERE, I., GARBEN, S. (Eds.). Interfaces between 
European and International Law (pp. 101-124). (Modern Studies in European Law; Vol. 89). Oxford: Hart Publishing, 2019. https://doi.org/10.5040/9781509923410.

EIDE, Asbjørn. Economic, social and cultural rights as human rights. In: EIDE, Asbjørn; KRAUSE, Catarina; ROSAS, Allan. Economic, social and cultural rights: a textbook. Dordrecht: Martinus Nijhoff, 1995, p. 21-40.

EPSTEIN, Lee; KNIGHT, Jack. Constitutional borrowing and non borrowing. International journal of constitutional law. New York, v. 1, n. 2, ap. 2003, p. 196-223.

FARBER, Daniel A. Retained by the people: the "silent" ninth amendment and the constitutional rights Americans don't know they have. New York: Basic Books, 2007.

GARDNER, John. How law claims, what law claims. In: KLATT, Matthias (ed.). Institutionalized reason: the jurisprudence of Robert Alexy. Oxford: Oxford, 2012, p. 29-44.

GOUVEIA, Jorge Bacelar. Os direitos fundamentais atípicos. Lisboa: Aequitas, 1995.

GREWE, Constance. Les influences du droit allemand des droits fondamentaux sur le droit français: le rôle médiateur de la jurisprudence de la Cour Européenne des Droits de l'Homme. Révue universelle des droits de l'homme, 2004, oct., v. 16, n. 1-4, p. 26-32.

GRIMM, Dieter. Constitucionalismo y derechos fundamentales. Madrid: Trotta, 2006. 214 p.

GRIMM, Dieter. The achievement of constitutionalism and its prospects in a changed world. In: DOBNER, Petra; LOUGHLIN, Martin. The twilight of constitutionalism? Oxford: Oxford, 2012, p. 3-22.

GRIMM, Dieter. The role of fundamental rights after sixty-five years of constitutional jurisprudence in Germany. International Journal of Constitutional Law, vol. 13, Issue 1, January 2015, Pages 9-29, https://doi.org/10.1093/icon/mov005.

GUASTINI, Riccardo. Teoría e ideología de la interpretación constitucional. Madrid: Trotta, 2008.

HABERMAS, Jürgen. Direito e democracia: entre facticidade e validade. v. I. Rio de Janeiro:Tempo Brasileiro, 2012.

HABERMAS, Jürgen. O conceito de dignidade humana e a utopia realista dos direitos humanos. In: HABERMAS, Jürgen. Sobre a constituição da Europa: um ensaio. [Tradução de Denilson Luis Werle, Luiz Repa, Rúrion Melo] São Paulo: Unesp, 2012, p. 7-37.

HABERMAS, Jürgen. The concept of human dignity and the realistic utopia of human rights. Metaphilosophy, vol. 41, no. 4, 2010, pp. 464-480. JSTOR, www.jstor.org/stable/24439631. Accessed 4 Jan. 2021.

HABERMAS, Jürgen. The inclusion of the other: studies in political theory. Cambridge: MIT Press, 1998. 
HABERMAS, Jürgen. The theory of communicative action. V. 1. Boston: Beacon. 1985.

HACHEM, Daniel Wunder. A dupla titularidade (individual e transindividual) dos direitos fundamentais econômicos, sociais, culturais e ambientais. Revista de Direitos Fundamentais e Democracia, v. 14, n. 14, Curitiba, p. 618-688, jul./dez. 2013.

HACHEM, Daniel Wunder; GUSSOLI, Felipe Klein. Animais são sujeitos de direito no ordenamento jurídico brasileiro? Revista Brasileira de Direito Animal, Salvador, v. 13, n. 3, p. 141-172, set./dez. 2017.

HANNUM, Hurst. Rescuing human rights: a radically moderate approach. Cambridge, Cambridge University Press, 2019.

HART, H. L. A. O conceito de direito. 5.ed. Lisboa: Calouste Gulbenkian, 2007.

HART, Herbert L. A. The concept of law. Oxford: Oxford, 2012, p. 100

HERRERA, Miguel Angel García. Prólogo a la segunda edición. In: BENDA, Ernst; MAIHOFER, Werner; VOGEL, Hans-Jochen; HESSE, Konrad; HEYDE, Wolfgang. Manual de derecho constitucional. 2.ed. Madrid: Marcial Pons, 2001, p. XLIII-LIX.

HESSE, Konrad. Constitución y derecho constitucional. In: BENDA, Ernst; MAIHOFER, Werner; VOGEL, Hans-Jochen; HESSE, Konrad; HEYDE, Wolfgang. Manual de derecho constitucional. 2.ed. Madrid: Marcial Pons, 2001, p. 1-15.

HESSE, Konrad. Significado de los derechos fundamentales. In: BENDA, Ernst; MAIHOFER, Werner; VOGEL, Hans-Jochen; HESSE, Konrad; HEYDE, Wolfgang. Manual de derecho constitucional. 2.ed. Madrid: Marcial Pons, 2001, p. 83-115.

JELLINEK, Georg. Reforma e mutación de la constitución. Madrid: Centro de Estudios Constitucionales, 1991.

JESTAEDT, Matthias. The doctrine of balancing: its strengths and weaknesses. In: KLATT, Matthias (ed.). Institutionalized reason: the jurisprudence of Robert Alexy. Oxford: Oxford, 2012, p. $152-172$.

KÄLIN, Walter; KÜNZLI, Jörg. The law of international human rights protection. Oxford: Oxford, 2009.

KANT, Immanuel. Groundwork of the metaphysics of Morals. Cambridge: Cambridge.

KLATT, Matthias. Robert Alexy's philosophy of law as system. In: KLATT, Matthias (ed.). Institutionalized reason: the jurisprudence of Robert Alexy. Oxford: Oxford, 2012, p. 1-26.

KLEMENT, Jan Hendrik. Common law thinking in German jurisprudence. In: KLATT, Matthias (ed.). Institutionalized reason: the jurisprudence of Robert Alexy. Oxford: Oxford, 2012, p. 173-200.

$\mathrm{KRISCH}$, Nico. Beyond constitutionalism: the pluralist structure of postnational law. Oxford: Oxford, 2010. $358 \mathrm{p}$. 
KRISCH, Nico. Global administrative law and the constitutional ambition. In: DOBNER, Petra; LOUGHLIN, Martin. The twilight of constitutionalism? Oxford: Oxford, 2012, p. 245-266.

KUMM, Mattias. Alexy's theory of constitutional rights and the problem of judicial review. In: KLATT, Matthias (ed.). Institutionalized reason: the jurisprudence of Robert Alexy. Oxford: Oxford, 2012, p. 201-217.

KUMM, Mattias. The best of times and the worst of times: between constitutional triumphalism and nostalgia. In: DOBNER, Petra; LOUGHLIN, Martin. The twilight of constitutionalism? Oxford: Oxford, 2012, p. 201-219.

KUMM, Mattias. The legitimacy of international law: a constitutionalist framework of analysis. The European Journal of International law, 2004, v. 15, n. 5, p. 907-931.

LAFONT, Cristina. Correctness and legitimacy in the discourse theory of law. In: KLATT, Matthias (ed.). Institutionalized reason: the jurisprudence of Robert Alexy. Oxford: Oxford, 2012, p. 291-306.

LARENZ, Karl. Metodologia da ciência do direito. [Tradução de José Lamego da 6. ${ }^{a}$ edição alemã de 1991] 3.ed. Lisboa: Fundação Calouste Gulbenkian, 1997.

LEIJTEN Ingrid. Core socio-economic rights and the European Court of Human Rights. Cambridge: Cambridge, 2018.

LOUGHLIN, Martin. What is constitutionalisation? In: DOBNER, Petra; LOUGHLIN, Martin. The twilight of constitutionalism? Oxford: Oxford, 2012, p. 47-69.

MACCARTHY, Thomas. La teoría crítica de Jürgen Habermas. Madrid: Tecnos, 1987.

MAIHOFER, Werner. Principios de una democracia en libertad. In: BENDA, Ernst; MAIHOFER, Werner; VOGEL, Hans-Jochen; HESSE, Konrad; HEYDE, Wolfgang. Manual de derecho constitucional. 2.ed. Madrid: Marcial Pons, 2001, p. 217-323.

MASSEY, Calvin R. Silent rights: the ninth amendment and the Constitution's unenumerated rights. Philadelphia: Temple University, 1995.

MAUS, Didier. Le recours aux précédents étrangers et le dialogue des cours constituionnelles. Revue française de droit constitutionnel. Paris, n. 80, oct., 2009, p. 675-696.

MCCRUDDEN, Christopher. Human dignity and judicial interpretation of human rights. European Journal of International Law. http//ssrn.com/abstract=1162024, accessed 06.01.2014.

MICHAEL, Lothar. Los derechos de igualdad como principios iusfundamentales. In: SIECKMANN, Jan-R. (ed.) La teoría principialista de los derechos fundamentales: estudios sobre la teoría de los derechos fundamentales de Robert Alexy. Madrid: Marcial Pons, 2011, p. 137-167.

MIRANDA, Jorge. A abertura constitucional a novos direitos fundamentais. Estudos em homenagem ao professor doutor Manuel Gomes da Silva. Coimbra: Coimbra, 2001, 559-572. 
MODUGNO, Franco. Interpretazione per valori e interpretazione costituzionale. In: AZZARITI, Gaetano. Interpretazione costituzionale. Torino: Giappichelli, 2005, p. 51-81.

MURPHY, Mark C. Defect and deviance in natural law jurisprudence. In: KLATT, Matthias (ed.). Institutionalized reason: the jurisprudence of Robert Alexy. Oxford: Oxford, 2012, p. 45-60.

NETTO, Luísa Cristina Pinto e. A abertura do sistema de direitos fundamentais do Estado Constitucional. Curitiba: Íthala, 2016.

NETTO, Luísa Cristina Pinto e. O princípio de proibição de retrocesso social. Porto Alegre: Livraria do Advogado, 2010.

NOLLKAEMPER, Andre, Conversations Among Courts: Domestic and International Adjudicators. In ALTER, Karin, ROMANO, Cesare, SHANY, Yuval (eds), Handbook of International Adjudication (OUP 2013, Forthcoming), Amsterdam Law School Research Paper No. 2013-30, Amsterdam Center for International Law No. 2013-08, AvailableSSRN: https://ssrn.com/abstract=2270565 or http://dx.doi.org/10.2139/ssrn.2270565.

OTERO, Paulo. Direitos históricos e não tipicidade pretérita dos direitos fundamentais. In: Ab vno ad omnes: 75 anos da Coimbra Editora. Coimbra: Coimbra, 1995, p. 1061-1090.

PARKER, Karen. Jus Cogens: compelling the law of human rights. Hastings Int'l \& Comp. L. Rev, v. 12, n. 2, p. 411-463, 1989.

PECES-BARBA MARTÍNEZ, Gregorio; ASÍS ROIG, Rafael; BARRANCO AVILÉS, María del Carmen. Lecciones de derechos fundamentales. Madrid: Dykinson, 2004.

PÉREZ LUÑO, Antonio Enrique. Derechos humanos, estado de derecho y constitución. 9.ed. Madrid: Tecnos, 2005.

PETERS, Anne. Are we moving towards constitutionalization of the world community? In: CASSESE, Antonio. Realizing utopia: the future of international law. Oxford: Oxford, 2012, p. 119-135.

PETERS, Anne. Compensatory constitutionalism: the function and potential of fundamental international norms and structures. Leiden Journal of International Law, 2006, 19, p. 579-610.

PETERS, Anne. Corruption as a Violation of International Human Rights, European Journal of International Law, vol. 29, n. 4, p. 1251-1287, nov. 2018.

PETERS, Anne. Humanity as the $A$ and $\Omega$ of sovereignty. The European Journal of International Law, v. 20, n. 3, p. 513-544, 2009.

PETERS, Anne. Membership in the global constitutional community. In: KLABBERS, Jan; PETERS, Anne; ULFSTEIN, Geir. The constitutionalization of international law. Oxford: oxford, 2009, p. 153-262. 
PETERS, Anne. Membership in the global constitutional community. In: KLABBERS, Jan; PETERS, Anne; ULFSTEIN, Geir. The constitutionalization of international law. Oxford: oxford, 2009, p. 153-262.

PIEROTH, Bodo; SCHLINK, Bernhard. Grundrechte, Staatsrecht II, 11.ed., Heidelberg: C. F. Müller, 1995.

PIOVESAN, Flávia. Direitos humanos e o direito constitucional internacional. 13.ed. São Paulo: Saraiva, 2012.

PIOVESAN, Flávia. Igualdade, diferença e direitos humanos. Rio de Janeiro: Lumen Juris, 2010.

PONTHOREAU, Marie-Claire. La reconnaisance des droits non-écrits par les cours constitutuionnelles italienne et française: essai sur le pouvoir créateur du juge constitutionnel. Paris: Economica, 1994.

POSCHER, Ralf. Aciertos, errores y falso autoconcepto de la teoría de los princípios. In: SIECKMANN, Jan-R. (ed.) La teoría principialista de los derechos fundamentales: estudios sobre la teoría de los derechos fundamentales de Robert Alexy. Madrid: Marcial Pons, 2011, p. 71-92.

POSCHER, Ralf. The principles theory: how many theories and what is their merit? In: KLATT, Matthias (ed.). Institutionalized reason: the jurisprudence of Robert Alexy. Oxford: Oxford, 2012, p. 218-247.

PULIDO, Carlos Bernal. El principio de proporcionalidad y los derechos fundamentales: el principio de proporcionalidad como criterio para determinar el contenido de los derechos fundamentales vinculante para el Legislador. 3.ed. Madrid: Centro de Estúdios Políticos y Constitucionales, 2007.

PULIDO, Carlos Bernal. Estudio introductorio. In: ALEXY, Robert. Teoría de los derechos fundamentales. Madrid: Centro de Estudios Políticos y Constitucionales, 2007, p. XXV-LXXX.

PULIDO, Carlos Bernal. La fuerza vinculante de la jurisprudencia en el orden jurídico colombiano. In: CAVINO, Massimo (a cura di). Esperienze di diritto vivente: la giurisprudenza negli ordinamenti di diritto legislativo: Italia, Francia, Belgio, Germania, Spagna, Portogallo, Brasile, Argentina, Colombia. Milano: Giuffrè, 2009. v.1, p. 279-312.

RANCHORDAS, Sofia. The Digitalization of Government and Digital Exclusion: Setting the Scene (April 29, 2020). University of Groningen Faculty of Law Research Paper , forthcoming In: Ferreira Mendes, G. \& Blanco de Morais, C. (eds.). Direito Publico e Internet: Democracia, Redes Sociais e Regulação do Ciberespaço FGV Publicacoes/IDP/ Univ. Lisboa, (Public Governance 4.0, 2020)., Available at SSRN: https://ssrn.com/abstract=3663051 or http://dx.doi.org/10.2139/ssrn.3663051.

ROSENKRANTZ, Carlos F. Against borrowings and other nonauthoritative uses of foreign law. Constitutional borrowing and non borrowing. International journal of constitutional law, New York, v. 1, n. 2, ap. 2003, p. 269-295. 
RÜTHERS, Bernd; FISCHER, Christian; BIRK, Axel. Rechtstheorie mit juristischer Methodenlehre. 6. Auf. München: C. H. Beck, 2011.

SANCHÍS, Luis Prieto. Justicia constitucional y derechos fundamentales. Madrid: Trotta, 2003. SARLET, Ingo Wolfgang. A eficácia dos direitos fundamentais. 10.ed. Porto Alegre: Livraria do Advogado, 2009.

SCHAUER, Frederick. Balancing, subsumption, and the constraining role of legal text. In: KLATT, Matthias (ed.). Institutionalized reason: the jurisprudence of Robert Alexy. Oxford: Oxford, 2012, p. 307-316.

SCHEININ, Martin. Economic, social and cultural rights as legal rights. In: EIDE, Asbjørn; KRAUSE, Catarina; ROSAS, Allan. Economic, social and cultural rights: a textbook. Dordrecht: Martinus Nijhoff, 1995, p. 41-62.

SCHILL, Stephan; TAMS, Christian J., HOFMANN, Rainer. International investment law and development: friends or foes? (2015). In SCHILL, Stephan; TAMS, Christian J.,

HOFMANN, Rainer (eds.). International investment law and development: bridging the gap (Cheltenham: Edward Elgar Publishing, 2015) 3-42. DOI: 10.4337/9781784711351.00008, Amsterdam Law School Research Paper No. 2017-26, Amsterdam Center for International Law No. 201722, Available at SSRN: https://ssrn.com/abstract=2934251.

SHAPIRO, Scott J., The Hart-Dworkin Debate: A short guide for the perplexed (March 5, 2007). (SSRN: https://ssrn.com/abstract=968657 or http://dx.doi.org/10.2139/ssrn.968657).

SIECKMANN, Jan-R. Los derechos fundamentales como princípios. In: SIECKMANN, Jan-R. (ed.) La teoría principialista de los derechos fundamentales: estudios sobre la teoría de los derechos fundamentales de Robert Alexy. Madrid: Marcial Pons, 2011, p. 27-50.

SIEGEL, Reva B. Dignity and the politics of protection: abortion restrictions under Casey/Carhart. Faculty Scholarship Series. 2008. Paper 1134. http://digitalcommons.law.yale.edu/ fss_papers/1134.

STERN, Klaus. Idee der Menschenrechte und Positivität der Grundrechte. In. ISENSEE, Josef; KIRCHHOF, Paul (Hrsg.). Handbuch des Staats Rechts. V, zweite Auflage. Heidelberg: Müller, 2000, p. 3-44.

STERN, Klaus. Idee und Elemente eines Systems der Grundrechte. In. ISENSEE, Josef; KIRCHHOF, Paul (Hrsg.). Handbuch des Staats Rechts. V, zweite Auflage. Heidelberg: Müller, 2000, p. 45-100.

SUNSTEIN, Cass; HOLME, Stephen. The cost of rights: why liberty depends on taxes. New York: Norton, 2013.

TASIOULAS, John. Are human rights taking over the space once occupied by politics? Newstatesmen (26, August, 2019). (<https://www.newstatesman.com/2019/08/are-human-rights-takingover-space-once-occupied-politics $>$ accessed 07.02.2020). 
TASIOULAS, John. Custom, jus cogens, and human rights. In: BRADLEY, Curtis A. ed. Custom's future: international law in a changing world. Cambridge University Press, Forthcoming, < https:// papers.ssrn.com/sol3/papers.cfm?abstract_id=2581763\&download=yes > acessed 21 January 2020.

TEUBER, Gunther. Fragmented foundations: societal constitutionalism beyond the national state. In: DOBNER, Petra; LOUGHLIN, Martin. The twilight of constitutionalism? Oxford: Oxford, 2012, p. 327-341.

TEUBNER, Gunther. Constitutional fragments: societal constitutionalism and globalization. Oxford: Oxford, 2012.

TRIBE, Laurence H. American constitutional law. 2.ed. New York: The Foundation Press, 1988.

TRINDADE, Antônio Augusto Cançado. Tratado de direito internacional dos direitos humanos. v. I. Porto Alegre: Sergio Antonio Fabris, 1999.

TRINDADE, Antônio Augusto Cançado. Tratado de direito internacional dos direitos humanos. v. II. Porto Alegre: Sergio Antonio Fabris, 1999.

TUSHNET, Mark. Weak courts, strong rights. Princeton: Princeton University Press, 2009.

VENZKE, Ingo, Authoritative Interpretation (October 11, 2018) In: Max Planck Encyclopedia of International Procedural Law; Amsterdam Law School Research Paper No. 2018-28; Amsterdam Center for International Law No. 2018-10. Available at SSRN: https://ssrn.com/abstract=3264566.

VENZKE, Ingo, The Practice of Interpretation in International Law: Strategies of Critique (September 10, 2018). Accepted paper In: International Legal Theory: Foundations and Frontiers (edited by Jeff Dunoff \& Mark A. Pollack, CUP 2019); Amsterdam Law School Research Paper No. 2018-22; Amsterdam Center for International Law No. 2018-07. Available at SSRN: https://ssrn. com/abstract $=3247125$.

VENZKE, Ingo. Understanding the authority of international courts and tribunals: on delegation and discursive construction. Theoretical Inquiries In Law, 14(2), 381-409, 2013. https://doi. org/10.1515/til-2013-020.

WALDRON, Jeremy. Derecho y desacuerdos. Madrid: Marcial Pons, 2005.

WALKER, Neil. Habermas's European constitution: catalyst, reconstruction, refounding. (https:// doi.org/10.1111/eulj.12341).

WEBER, Albrecht. L'État social et les droits sociaux en RFA. Révue française de droit constitutionnel, Paris, n. 24, 1995, p. 677-693.

WEISS, Edith Brown. Intergenerational Equity in a Kaleidoscopic World, Environmental Policy and Law, vol. 49, no. 1, pp. 3-11, 2019. <https://content.iospress.com/download/environmental-policy-and-law/epl190115?id=environmental-policy-and-law\%2Fepl190115> accessed 21 January 2020. 
WEISS, Edith Brown. International Law in a Kaleidoscopic World (2011). Georgetown Law Faculty Publications and Other Works. 1622. https://scholarship.law.georgetown.edu/facpub/1622.

WESTON, Burns $\mathrm{H}$. The universality of human rights in a multicultured world: toward respectful decision-making. In WESTON, Burns H.; MARKS, Stephen P. (eds.). The future of international human rights. New York: Transnational. 1999, p. 65-99.

ZAGREBELSKY, Gustavo. El derecho dúctil: ley, derechos, justicia. 8.ed. Madrid: Trotta, 2008. 